\title{
RECUPERAÇÃO DE EMPRESAS EM AUTOGESTÃO NO BRASIL ATUAL: RESISTÊNCIAS DAS CLASSES TRABALHADORAS E POPULARES EM TEMPOS DE CRISE PANDÊMICA?
}

\author{
WORKER-RECUPERATED ENTERPRISES IN SELF-MANAGEMENT IN CURRENT \\ BRAZIL: RESISTANCE OF WORKING AND POPULAR CLASSES IN TIMES OF \\ PANDEMIC CRISIS?
}

\author{
Vanessa Moreira Sígolo ${ }^{1}$ \\ Fernanda Santos Araújo ${ }^{2}$ \\ Flávio Chedid Henriques ${ }^{3}$ \\ Vicente Nepomuceno ${ }^{4}$ \\ Tarcila Mantovan Atolini ${ }^{5}$
}

\section{RESUMO}

As experiências de recuperação de empresas em autogestão são expressões de resistência das classes trabalhadoras, presentes na história do capitalismo, em vários países. No Brasil, no fim de 1980 surgiram experiências em período de forte crise relacionada à integração do país aos processos de mundialização da economia e implantação de políticas neoliberais. $\mathrm{O}$ fenômeno gerou conquistas no enfrentamento ao desemprego, colocando em prática relações de trabalho e propriedade associativas, abrindo diálogos com universidades e outras lutas sociais. Todavia, o tema alcançou limitadas conquistas em políticas públicas e reduzido espaço no movimento sindical em contexto de crescimento econômico, e o refluxo de experiências caracterizou a última década. No cenário atual, de grave crise pandêmica somada aos retrocessos e violações a direitos humanos, sociais e do trabalho no país, essas experiências assumem relevância. Este artigo, em continuidade a pesquisas anteriores, analisa o panorama das experiências brasileiras em diálogo com outras, latino-americanas.

Palavras-chave: autogestão do trabalho, classes trabalhadoras e populares, crise pandêmica, empresas recuperadas por trabalhadores, resistências e lutas sociais.

\section{ABSTRACT}

The experiences of recuperated enterprises in self-management are expressions of working classes resistance, present throughout the history of capitalism, in many countries. In Brazil, in the late 1980s, experiences arise in a period of strong crisis related to the country's integration

\footnotetext{
1 Pós-doutoranda no Departamento de Sociologia da Universidade de São Paulo (USP), sob supervisão de Ruy Braga, e doutora por essa mesma instituição.

2 Professora do Núcleo Interdisciplinar para o Desenvolvimento Social da Universidade Federal do Rio de Janeiro (UFRJ).

3 Pós-doutorando no Centro de Estudos Sociais (CES) da Universidade de Coimbra, sob supervisão de Pedro Hespanha e Andrés Spognardi. Professor do Programa de Pós-Graduação em Tecnologia para o Desenvolvimento Social do Núcleo Interdisciplinar para o Desenvolvimento Social da Universidade Federal do Rio de Janeiro (UFRJ).

4 Professor do Departamento de Engenharia de Produção da Universidade Federal do Estado do Rio de Janeiro (UNIRIO).

5 Professora do Instituto de Ciência e Tecnologia da Universidade Federal dos Vales do Jequitinhonha e Mucuri (UFVJM).
} 
in the processes of economic globalization and implementation of neoliberal policies. The phenomenon has generated achievements in facing unemployment, putting into practice associative labour and property relations, opening dialogues with universities and other social struggles. Nevertheless, the subject has reached limited public policy achievements and reduced space in the union movement in context of economic growth, and the reflux of experiences characterized the last decade. In the current scenario of severe pandemic crisis, added to the country's serious setbacks and violations in human, social and labour rights, these experiences take on relevance. This article, continuing previous research, analyses the panorama of Brazilian experiences, in dialogue with other Latin-American experiences.

Keywords: self-management work, working and popular classes, pandemic crisis, workerrecuperated enterprises, social resistances and struggles.

\section{INTRODUÇÃO}

O quadro atual de colapso econômico e ambiental mundial nos convoca a debater sobre as resistências e desobediências à "normalidade" capitalista, que historicamente, e também em sua expressão neoliberal, reproduz e aprofunda a miséria, as desigualdades e a destruição da natureza e da vida em geral. Diante da "janela" que a crise pandêmica global abriu à reflexão profunda sobre o modo de vida contemporâneo, é de extrema relevância pesquisar sobre experiências de luta pela transformação das relações de produção, de organização do trabalho e de reprodução da vida social.

No cenário atual, de grave crise do país e global, agravada fortemente em contexto de pandemia, qual o balanço e o significado das experiências de recuperação de empresas por trabalhadores e trabalhadoras em autogestão? Aprofundando mais: há indícios do ressurgimento do fenômeno de recuperação de empresas por trabalhadores(as) no país, como ocorrido anteriormente na década de 1990? Quais fatores contribuem ou não para isso? Nos casos de empresas recuperadas em atividade, quais são suas características? Quem são as(os) trabalhadoras(es)? Quais são os atores envolvidos e as redes de sustentação econômica, política e social dessas experiências na atualidade? Como as recuperações de empresas por trabalhadores(as) se relacionam com as lutas sociais no contexto atual do mundo do trabalho capitalista? Que reflexões tais experiências suscitam para o debate sobre o cenário pós-pandemia na atualidade? Em contexto de disputa sobre caminhos para o enfrentamento da crise mundial, de acirramento das desigualdades sociais e dos conflitos de classes, qual o significado e as contribuições desse fenômeno diante do atual cenário de precarização dos direitos do trabalho e elevado desemprego? De que forma tais experiências compõem as lutas pela transformação do modo de produção e reprodução social e do modelo de desenvolvimento econômico e industrialização do capitalismo atual, que conduziram a humanidade às catástrofes sociais, ambientais e econômicas do tempo presente?

As experiências de recuperação de empresas por trabalhadores(as) são manifestações de resistência das classes trabalhadoras e populares que marcam a história da luta de classes em diversos países. Expressão do enfrentamento ao desemprego, à miséria e a formas capitalistas de exploração do trabalho, suas origens remontam às lutas associativistas do início da Revolução Industrial. Ao longo da história e também na atualidade, nessas experiências trabalhadores(as) têm colocado em prática, muitas vezes sem ter uma formulação clara do processo e dos significados de sua ação, novas relações de trabalho associativas, que se diferenciam das relações patrãoempregado e do assalariamento. Essas novas relações de trabalho têm sido identificadas em vários momentos da história e também hoje, com o conceito de autogestão, que se refere a um 
conjunto amplo de experiências de trabalho associado e de auto-organização de trabalhadores, com variadas origens, características e formas de organização, no qual se incluem as Empresas Recuperadas por Trabalhadores(as) (ERTs), como uma de suas expressões.

Apesar de marginais frente ao modo de produção hegemônico do sistema capitalista, a luta pela autogestão de trabalhadores(as) na recuperação de empresas compõe o "fazer-se" da classe trabalhadora na história, resgatando a expressão de E. P. Thompson (1987), em seu seminal estudo sobre o movimento operário inglês. Formando parte do conjunto de lutas do trabalho, as ERTs, como alguns estudos apontam, constituem uma prática concreta de resistência e ação direta, nas quais trabalhadores(as) buscam se tornar sujeitos de experiências coletivas, portadoras de inovações nas relações sociais de produção e trabalho (HENRIQUES et al., 2013; SÍGOLO, 2015; ARAÚJO et al., 2019).

No Brasil, as primeiras experiências de ERTs surgem nos anos 1980 e se multiplicam com maior intensidade nos anos 1990, no contexto de grave crise econômica, relacionada à abertura do mercado nacional, com a integração do país aos processos de mundialização da economia e a implantação de políticas neoliberais. Em meados dos anos 2000, estimou-se a existência de cerca de 200 experiências desse tipo no país ${ }^{6}$, mas o fenômeno vem decrescendo desde o final da primeira década do século. Hoje ainda persistem casos em atividade no Brasil, mas são pouco conhecidos pela sociedade mais ampla. No entanto, tais experiências constituem parte significativa da história da luta das classes trabalhadoras no contexto pós-implantação do neoliberalismo no país.

À luz dos debates históricos sobre autogestão do trabalho, e em diálogo com experiências de outros países (especialmente Argentina), em busca por contribuir com a compreensão, a divulgação e o fortalecimento dessas experiências, foi criado o Grupo de Pesquisa em Empresas Recuperadas por Trabalhadores(as) (GPERT). Formado por pesquisadores(as) e professores(as) de várias universidades brasileiras, de diferentes áreas, em especial da Engenharia de Produção e das Ciências Sociais, o grupo se dedica ao estudo das ERTs no Brasil e há uma década produz conhecimentos e também práticas extensionistas, com o intuito de criar referências para os(as) próprios(as) trabalhadores(as) em suas ações de resistência e luta, em direção à autogestão e à conquista de condições justas e dignas de trabalho e vida.

Em 2013, o grupo publicou o primeiro mapeamento nacional das empresas recuperadas brasileiras (HENRIQUES et al., 2013), como resultado de vários estudos, debates e reflexões sobre as características e práticas concretas de autogestão em experiências visitadas em campo. Reconhecendo que a pesquisa de campo, baseada em visitas de curta duração, não era suficiente para determinar quais experiências seriam ou não autogestionárias, para a inclusão de casos no universo da pesquisa o grupo optou por questionar as próprias empresas e considerar a autodeclaração dos(as) próprios(as) trabalhadores(as) sobre critérios mínimos relacionados à organização coletiva e o reconhecimento dos envolvidos de que a propriedade do empreendimento pertencia a um coletivo de trabalhadores(as).

Essa opção político-metodológica, entretanto, não impediu que a pesquisa identificasse distinções entre as empresas mapeadas, e que essas diferenças gerassem problematizações com relação a um ideal de democracia e de autogestão previamente concebido ao estudo em campo. Nas observações e análises dos casos, foi possível identificar elementos que influenciam a gestão democrática dos empreendimentos e permitem analisar os processos de autogestão, como: a abertura para novos sócios, o rodízio da direção, a participação do coletivo dos(as)

\footnotetext{
${ }^{6}$ Dados da Associação Nacional de Trabalhadores em Empresas de Autogestão (ANTEAG) (HENRIQUES et al., 2013).
} 
trabalhadores(as) nos espaços de poder, as diferenças entre as remunerações, o vínculo com movimentos sociais e princípios políticos, a relação entre o número de sócios(as) e de trabalhadores(as) contratados(as) e/ou terceirizados(as), bem como a influência exercida por assessores(as), parceiros(as) e também pela figura jurídica adotada na gestão da empresa.

Desde o início, o trabalho de pesquisa afastou-se de uma visão apenas teórica do conceito de autogestão e dedicou-se a compreender as experiências por meio das práticas estudadas, de suas características e seus desafios, e a extrair elementos que pudessem fortalecer a gestão das empresas por seu coletivo de trabalhadores(as). Ao longo de sua trajetória, o grupo pôde avançar nas compreensões (múltiplas) das experiências de recuperação de empresas por trabalhadores(as) no Brasil, e também na construção de aproximações e práticas de cooperação com trabalhadores(as) dessas empresas.

Entre os trabalhos acadêmicos que se propõem a analisar as experiências de ERTs e também de outras empresas identificadas ao campo da autogestão e da Economia Solidária, verifica-se com certa recorrência que se reproduz uma concepção "ideal" de autogestão, associada a determinada "receita" de práticas, que por vezes é utilizada para avaliar as experiências (ARAÚJO et al., 2019). Embora esses trabalhos contribuam para o desenvolvimento do estudo sobre o fenômeno, nas pesquisas desenvolvidas pelo GPERT parte-se de caminho político-metodológico distinto, ao considerar que a aplicação de uma visão teórica-normativa aos casos limita e restringe as possibilidades de compreensão da realidade, das dificuldades e dos desafios desses processos e lutas por autogestão.

Essa postura, que orienta o desenvolvimento das pesquisas do grupo e a aproximação às experiências, resulta do interesse em investigar as potencialidades que elas apresentam para a emergência de relações sociais identificadas com modelos societários democráticos e emancipatórios. Mas também é decorrente do reconhecimento das limitações de pesquisas que buscam teorizar sobre algo que é vivido pelo outro. Apesar de contar com vivências em coletivos de trabalho e militância aproximados às experiências da autogestão, o grupo é formado por pesquisadores e pesquisadoras que não são trabalhadores(as) autogeridos(as) e não dependem dessa forma de organização para conquistar os elementos materiais básicos para sua sobrevivência. Portanto, engajado em impulsionar tais experiências, o grupo busca, em seus trabalhos, estar atento aos riscos de uma visão "colonialista do saber" e evitar exercer o papel do(a) acadêmico(a) que constrói julgamentos e normatizações sobre experiências (SANTOS, 2016).

Assim, as pesquisas do grupo buscam identificar as lutas por autogestão em experiências concretas de empresas nas quais um conjunto de pessoas que vivem do próprio trabalho passa a tomar decisões estratégicas em seus coletivos, compreendendo-se estas lutas como processos por vezes repletos de contradições, pelos quais trabalhadores(as) buscam se tornar sujeitos na conquista e manutenção de seu trabalho e de sua vida. Essa condição pode ser base para a construção de relações sociais pautadas em princípios democráticos e de justiça social, com avanços na igualdade de gênero, na promoção de relações responsáveis e solidárias com a comunidade externa e com os recursos naturais, na eficiência da produção, com distribuição democrática e justa de benefícios e excedentes, entre outros fatores que apontam para um projeto de sociedade com justiça social, econômica e ambiental.

Ao olhar a autogestão na prática, em suas características e contradições, pretende-se contribuir com a compreensão sobre em que medida, nas experiências das ERTs brasileiras, são criadas novas relações sociais democráticas e emancipatórias, e também em que medida há nelas a reprodução de relações de exploração, desigualdade e precarização do trabalho, para colocar tais estudos e pesquisas a serviço dos próprios trabalhadores(as) em suas construções coletivas. 
O conceito de autogestão, conforme analisam alguns autores ${ }^{7}$, surge nos anos 1950 , apresentado pelo Partido Comunista iugoslavo, por meio da palavra servo-croata samoupravlje. O termo foi traduzido por dicionários franceses na década de 1960 e referia-se à experiência da Iugoslávia de Tito, em contraposição ao stalinismo. Relacionada ao movimento de libertação da classe trabalhadora, a ser alcançada pela associação autônoma de produtores, a formulação remete a concepções de Karl Marx, na obra Manuscritos econômicos de 1844: "a opressão humana inteira está envolvida na relação do trabalhador com a produção, e todas as relações de servidão são apenas modificações e consequências dessa relação" (MARX, 2004, p. 89).

Inspirado nesses escritos e nos acontecimentos do Maio de 68 na França, o conceito de autogestão popularizou-se nos movimentos estudantis e operários anticapitalistas. A propagação maior ocorreu no contexto da crise do petróleo dos anos 1970, com autores, sindicalistas e militantes franceses, que tiveram papel fundamental para sua divulgação, tornando o tema "incontornável" no debate político do movimento socialista e operário no período (SÍGOLO, 2015). O conceito foi utilizado por diferentes perspectivas teórico-políticas, incluindo vertentes socialistas, libertárias, anarquistas e humanista-cristãs (SÍGOLO, 2007). Ao denominar inúmeras experiências, Daniel Mothé (1980) identifica diferentes níveis da luta por autogestão: pela superação do taylorismo na própria atividade de produção do trabalhador; pela cooperação entre os trabalhadores; pela gestão coletiva de oficinas de produção; pela gestão coletiva da empresa e pela gestão coletiva do conjunto da sociedade.

Seguindo o rastro dessas lutas sociais, nos últimos 30 anos, no Brasil, milhares de trabalhadores(as) têm lutado e se associado para recuperar empresas e manter seu trabalho sob gestão coletiva. Em alguns casos, conquistaram a propriedade coletiva e alcançaram a viabilidade da produção da empresa sob autogestão dos(as) trabalhadores(as) por mais de 20 anos.

Para acompanhar essas experiências em nosso país, o grupo de pesquisa realizou o primeiro mapeamento de Empresas Recuperadas por Trabalhadores(as) no Brasil (já citado) e, nos anos seguintes, se propôs a assessorar três casos para, assim, aprofundar o conhecimento sobre os processos de autogestão vivenciados por eles. Em paralelo ao trabalho coletivo de assessoria, alguns membros desenvolveram pesquisas acadêmicas individuais sobre o tema, e o grupo acolheu novos integrantes, que também realizavam pesquisas e encontraram nele um espaço para trocar experiências e conhecer melhor o conjunto de casos no país. Os resultados dos trabalhos desenvolvidos nesse período foram publicados em Dialética da autogestão em empresas recuperadas por trabalhadores no Brasil (ARAÚJO et al., 2019).

No Brasil, vive-se na atualidade um momento histórico de gravíssima crise econômica, política, social e ambiental, agravada fortemente pela pandemia do novo coronavírus, que gerou e segue gerando diversos retrocessos, especialmente no campo dos direitos do trabalho e das políticas sociais. Nesse contexto, as lutas autogestionárias e as experiências de recuperação de empresas por trabalhadores(as) ganham renovada relevância.

Neste artigo, o grupo apresenta análises e reflexões sobre o fenômeno na atualidade, produzidas com base nessa trajetória e também na recente atualização de informações, no contexto da pandemia, sobre os casos mapeados anteriormente no país. Acredita-se que este trabalho ajuda a construir um balanço dessas experiências no Brasil atual e a avançar na reflexão sobre o conceito e as práticas de autogestão do trabalho com base em uma perspectiva que tem na empiria, e nas contradições que ela suscita, os principais elementos para a busca da compreensão das experiências de gestão coletiva de trabalhadores(as) que reverteram o processo de falência de suas empresas e seguem lutando para manter seu trabalho.

\footnotetext{
7 Guillerm e Bourdet, 1976; Nascimento, 2005; Faria, 2011; Sígolo, 2015, entre outros.
} 
Partindo do concreto e buscando compreender as contradições como parte integrante das experiências autogestionárias, este trabalho se inspira na obra de Henri Lefebvre (1995) e em sua lógica dialética e concreta, da construção de uma teoria do conhecimento entendida também como história da prática social. No percurso da pesquisa, que se desenvolveu como pesquisa-ação (THIOLLENT, 2020), foram identificadas características nas ERTs que remetem a formas capitalistas de organização do trabalho, as quais são inclusive amplificadas em períodos de crise. Sem considerar que as contradições "degeneram" as experiências, a proposta foi analisá-las como parte delas, e por vezes como as características mais expressivas e destacadas. Em um exercício dialético, busca-se reconhecer as contradições dos processos de luta pela autogestão e situar temporal e territorialmente as experiências concretas. Como também orienta Paul Singer (1998), procura-se ainda estudar o movimento das práticas de empresas recuperadas, reconhecendo que formas capitalistas coexistem com novas formas, práticas e relações sociais, portadoras de características e elementos de superação da lógica do capital.

Inspirado nesses pensadores militantes, este artigo, em sua primeira parte, apresenta informações gerais sobre o fenômeno das recuperações de empresas por trabalhadores(as) no Brasil. Com base nos dados coletados no primeiro mapeamento nacional, publicado em 2013, e da atualização produzida em 2017, foi realizada em 2020 a coleta de algumas informações atuais sobre o conjunto das experiências brasileiras, no contexto da crise pandêmica. A segunda parte do texto trata de um conjunto de breves relatos de diálogos realizados com quatro casos de ERTs no contexto de crise atual. Com eles, busca-se retomar histórias singulares e também analisar características expressivas do conjunto das experiências brasileiras. Na terceira parte do trabalho são problematizadas questões sobre o momento atual das recuperações de empresas por trabalhadores(as) no país, as quais geraram subsídios para a elaboração de uma proposta de agenda futura de pesquisas sobre a temática, descrita nas considerações finais.

\section{BREVE PANORAMA DAS EMPRESAS RECUPERADAS NO BRASIL:}

No mapeamento nacional de casos empreendido entre 2011 e 2013 pelo GPERT, houve um extenso trabalho de localizar e identificar as experiências em atividade no país. Com indícios de que havia mais casos do que aqueles assessorados na época pelas entidades de representação existentes ${ }^{8}$, juntamente às listagens dessas organizações foram consultados os dados do Sistema Nacional de Economia Solidária (SIES) ${ }^{9}$ e também usada a estratégia de perguntar às experiências visitadas sobre outras iniciativas ainda não listadas na pesquisa.

Nesse período, a pesquisa identificou 67 casos de ERTs em funcionamento no país, com visitas em campo à maior parte dos casos (52 experiências). Também foram identificados 78 outros casos de recuperação que haviam encerrado (ou seja, que existiram, mas não estavam mais em atividade) e outros 85 casos sobre os quais não foram obtidas informações definitivas para confirmar se eram ERTs e se estavam em atividade. Embora não seja possível uma análise comparativa de dados ao longo do tempo, pois esse foi o primeiro mapeamento realizado em âmbito nacional, pelo número de casos encerrados e por haver poucos casos recentes, a pesquisa apontou que as experiências no Brasil tendiam à diminuição.

Nesse primeirolevantamentorealizadopelogrupo foramidentificados aproximadamente 12 mil trabalhadores(as) envolvidos(as) nas ERTs, na maior parte homens. Presentes em quatro regiões brasileiras (exceto no Centro-Oeste), os casos concentravam-se principalmente

\footnotetext{
${ }^{8}$ Central de Cooperativas e Empreendimentos Solidários (UNISOL Brasil) e Associação Nacional de Empresas de Autogestão (ANTEAG).

9 Dados da Secretaria Nacional de Economia Solidária do Ministério do Trabalho e Emprego (SENAES-MTE).
} 
no Sudeste e no Sul do país, com destaque ao estado de São Paulo, com exemplos, como a Uniforja (Cooperativa Central de Produção Industrial de Trabalhadores em Metalúrgica), em Diadema-SP; a Flaskô Embalagens Plásticas, em Sumaré-SP; e a Uniwidia (Cooperativa Industrial de Trabalhadores em Ferramentas de Metal Duro), em Mauá-SP.

Verificou-se também nesta pesquisa que a maioria dos casos tinha a forma jurídica de cooperativa (85\%), pequeno porte - até 100 trabalhadores(as) - e a metade dos casos era do setor metalúrgico. Este estudo também identificou alguns casos de grandes empresas, com mais de 500 trabalhadores(as), como a Usina Catende, em Pernambuco, e a Cooperminas, em Santa Catarina.

Sobre o surgimento dos casos, a pesquisa revelou que os mais antigos tiveram origem no início dos anos 1980. Intensificando-se nos anos 1990, a metade das experiências pesquisadas relatou o uso de medida de força (ocupação ou acampamento) e a maioria apontou ter recebido apoio de sindicatos (especialmente das chamadas oposições sindicais), movimentos sociais ou grupos religiosos, como pastorais. Além disso, na pesquisa foram relatadas mudanças na organização do trabalho: no sentido da descentralização, redução de hierarquias e maior acesso à informação; maior rodízio de atividades e colaboração no trabalho; maior flexibilidade, autonomia e liberdade (de horário, função e posto); melhorias nas condições de saúde e segurança do trabalho, com redução de acidentes; e diminuição de diferenças entre a maior e a menor remuneração (sendo em média 4,7 vezes). Dentre as organizações de apoio e representação das empresas recuperadas no Brasil, foram citadas: ANTEAG, UNISOL Brasil, Movimento de Fábricas Ocupadas e Fórum Brasileiro de Economia Solidária (FBES).

Após a publicação do primeiro mapeamento, em 2013, o GPERT se propôs a acompanhar a situação das recuperações de empresas por trabalhadores(as) no Brasil. Sobre a tendência à queda no número de casos no país, uma das hipóteses elencadas naquele momento estava relacionada ao bom momento econômico vivido nos anos anteriores, que não só gerava a redução do número de falências, como também apresentava alternativas de emprego para trabalhadores(as) de empresas falidas. Partindo dessa hipótese, o novo contexto motivou o grupo a questionar se a crise econômica vivida a partir de 2013 geraria um aumento no número de recuperações de empresas por trabalhadores(as) no país.

Em atualização de dados realizada em 2017, com um questionário mais curto, aplicado por telefone ou enviado por e-mail às empresas, foi revisada a lista de ERTs do mapeamento anterior. Dos 67 casos mapeados em 2013, foi confirmado o encerramento de 20 experiências. Essa segunda pesquisa ocorreu em um contexto de aprofundamento da crise econômica do país, especialmente após o golpe parlamentar de 2016, e confirmou o "refluxo das experiências" brasileiras. Apesar do número significativo de ocupações de empresas por trabalhadores registrado pelo grupo no período, foi confirmada na pesquisa a consolidação de apenas um novo caso. Além disso, naquele momento, foram identificados três casos que já existiam antes de 2013, mas que não haviam sido mapeados anteriormente, totalizando 51 casos ativos no país em 2017, de acordo com os dados coletados na pesquisa.

\section{Atualização de dados sobre as ERTs no Brasil em 2020}

Com base no universo de empresas recuperadas identificadas como ativas em 2017, foi realizado um novo levantamento em 2020, no contexto da pandemia ${ }^{10}$. Em um processo excepcional de aprofundamento da crise global e no país, esse esforço de atualização de

\footnotetext{
${ }^{10}$ Além dos autores do presente artigo, também contribuíram para o levantamento de dados realizado em 2020: Sandra Rufino, Lucca Pérez Pompeu e Cícero Hernandez.
} 
informações sobre os casos brasileiros foi motivado pelo questionamento sobre como as ERTs brasileiras estariam reagindo a essa crise.

O contato, por telefone, com as empresas que compunham a listagem anterior ocorreu no período de maio a agosto de 2020. Em alguns casos, apenas foi possível confirmar se a empresa estava em atividade ou não; em outros casos, foram coletadas algumas informações adicionais sobre a situação da empresa no momento. Com quatro empresas, foram realizadas entrevistas mais aprofundadas (abordadas na seção seguinte deste artigo). Infelizmente, há casos em que não foi obtido nenhum tipo de informação conclusiva ou contato. Com esse esforço, concluiu-se que, das 51 ERTs presentes na listagem de 2017,

- 31 permanecem ativas, com produção ${ }^{11}$;

- cinco foram encerradas, sendo que em um caso se verificou a criação de nova empresa e forma jurídica, mas não foi possível confirmar se segue presente a perspectiva de autogestão;

- duas estão temporariamente paradas devido à pandemia, mas com perspectiva de retomada ${ }^{12}$;

- duas estão paradas, em luta coletiva pela retomada da produção;

- uma permanece ocupada pelos trabalhadores(as), mas sem perspectiva de retomada da produção. Nessa empresa, os(as) trabalhadores(as) estão em luta pelos ativos da empresa e engajados em outras lutas populares;

- Das 10 restantes com as quais não foi possível estabelecer contato ou obter informação mais precisa, aparentemente quatro estão inativas e seis ativas ${ }^{13}$.

Cabe ressaltar que não foram registrados novos casos; todavia, esse não foi o foco da atualização empreendida pelo grupo neste trabalho ${ }^{14}$. Certamente, essa é uma tarefa para a continuidade da pesquisa, como também a revisão da metodologia utilizada para a identificação de novos casos, pois se estão surgindo nesse momento, ou nos últimos anos, não estão em contato com as experiências anteriores e as entidades que articulavam historicamente suas lutas no país. Diante disso, é importante seguir investigando novos contextos e atores junto aos quais grupos de trabalhadores(as) possam estar se organizando coletivamente para recuperar empresas em crise ou situação falimentar. Como encontrá-los e estabelecer diálogos com as experiências, entre elas e destas com as experiências anteriores são perguntas e reflexões que serão retomadas na parte final deste artigo.

$\mathrm{Na}$ pesquisa atual, com as informações obtidas por meio de contato telefônico com os casos, elaborou-se um quadro comparativo da situação das empresas nos três momentos de pesquisa do GPERT (2012, 2017 e 2020), levando-se em consideração a variação no número de trabalhadores(as) envolvidos(as) e um indicador não objetivo do momento da produção.

\footnotetext{
${ }^{11}$ Juntamente aos 18 casos citados no quadro a seguir, verificou-se que estão ativas: CAEB, Cooperleo, CFF, Haga, CDM, Cooperfor, Cooperlafe e Coopertratt, Polyutil, Coopercana, Coopercheide, Reticooper, Cootrans.

${ }^{12}$ Cooperativa Monte Sinai e Coophotel.

${ }^{13}$ Não foram realizados contatos diretos com essas empresas, por isso foram consideradas "aparentemente ativas" aquelas cujo site está atualizado ou a respeito das quais há alguma notícia recente sobre sua atividade, e "aparentemente inativas" aquelas sobre as quais não foram encontrados indícios de atividade. Em ambos os casos, as pesquisas não foram conclusivas.

${ }^{14}$ Em sua tese de doutorado, Ribeiro (2018) faz referência a três cooperativas do ramo da educação no Rio Grande do Sul, que, segundo o autor, são provenientes de processos falimentares, anteriores a 2017 (de 2000, 2008 e 2014). Esses casos não foram identificados nos mapeamentos anteriores e podem ser considerados para pesquisas futuras.
} 
QUADRO 1 - SITUAÇÃO DAS EMPRESAS NOS TRÊS LEVANTAMENTOS DO GPERT (2012, 2017 E 2020)

\begin{tabular}{|c|c|c|c|c|c|c|c|}
\hline \multirow{2}{*}{ Nome da empresa } & \multirow{2}{*}{ Estado } & \multirow{2}{*}{ Setor } & \multirow{2}{*}{$\begin{array}{l}\text { Ano do } \\
\text { início do } \\
\text { processo de } \\
\text { recuperação }\end{array}$} & \multicolumn{3}{|c|}{ Número de trabalhadores } & \multirow{2}{*}{ Produção } \\
\hline & & & & 2012 & 2017 & 2020 & \\
\hline \multicolumn{8}{|c|}{ Empresas aparentemente em declínio } \\
\hline CONES & SP & Têxtil & 1998 & $\begin{array}{l}\text { Total: } 274 \\
187 \text { sócios } \\
87 \text { contratados }\end{array}$ & - & $\begin{array}{l}\text { Total: } 165 \\
150 \text { sócios } \\
15 \text { contratados }\end{array}$ & $\begin{array}{l}\text { Em } 2020 \text { disseram que a produção está um pouco } \\
\text { menor do que nos últimos anos. }\end{array}$ \\
\hline COOPEREI & $\mathrm{RS}$ & Metalúrgico & 2001 & $\begin{array}{l}\text { Total: } 37 \\
32 \text { sócios } \\
5 \text { contratados }\end{array}$ & - & 21 & $\begin{array}{l}\text { Em } 2020 \text { disseram que a produção está um pouco } \\
\text { menor do que nos últimos anos. }\end{array}$ \\
\hline COOPERINCA & SP & $\begin{array}{l}\text { Turismo/ } \\
\text { /hotelaria }\end{array}$ & 1994 & $\begin{array}{l}\text { Total: } 15 \\
13 \text { sócios } \\
2 \text { contratados }\end{array}$ & 4 & $\begin{array}{l}\text { Total: } 13 \\
6 \text { sócios } \\
7 \text { contratados }\end{array}$ & Bastante afetada pela pandemia. \\
\hline UNIFORJA & SP & Metalúrgico & 1997 & $\begin{array}{l}\text { Total: } 497 \\
295 \text { sócios } \\
202 \text { contratados }\end{array}$ & $\begin{array}{l}\text { Total: } 322 \\
213 \text { sócios } \\
88 \text { contratados }\end{array}$ & $\begin{array}{l}\text { Total: } 293 \\
213 \text { sócios } \\
80 \text { contratados }\end{array}$ & $\begin{array}{l}\text { Em } 2017 \text { relataram que a produção vinha reduzin- } \\
\text { do. Hoje disseram que perderam por volta de } 40 \% \\
\text { da capacidade de produção de } 2008 \text { para cá. }\end{array}$ \\
\hline ALUMIFER & $\mathrm{RS}$ & Metalúrgico & 1998 & $\begin{array}{l}\text { Total: } 28 \\
21 \text { sócios } \\
7 \text { contratados }\end{array}$ & $\begin{array}{l}\text { Total: } 25 \\
11 \text { sócios } \\
14 \text { contratados }\end{array}$ & $\begin{array}{l}\text { Total: } 12 \\
8 \text { sócios } \\
4 \text { contratados }\end{array}$ & $\begin{array}{l}\text { Em } 2020 \text { disseram que a produção vem reduzindo } \\
\text { nos últimos anos. }\end{array}$ \\
\hline PLASTCOOPER & SP & Plástico & 1999 & $\begin{array}{l}\text { Total: } 85 \\
31 \text { sócios } \\
54 \text { contratados }\end{array}$ & - & $\begin{array}{l}\text { Total: } 10 \\
7 \text { sócios } \\
3 \text { contratados }\end{array}$ & $\begin{array}{l}\text { Vêm enfrentando grandes dificuldades desde } \\
2015 \text {. }\end{array}$ \\
\hline COOPEVAL & SP & Alimentação & 2004 & $\begin{array}{l}\text { Total: } 170 \\
150 \text { sócios } \\
20 \text { contratados }\end{array}$ & - & $\begin{array}{l}\text { Total: } 100 \\
40 \text { sócios } \\
60 \text { contratados }\end{array}$ & $\begin{array}{l}\text { Em } 2020 \text { disseram que a produção está um pouco } \\
\text { menor do que nos últimos anos. }\end{array}$ \\
\hline METALCOOP & SP & Metalúrgico & 2002 & $\begin{array}{l}\text { Total: } 124 \\
51 \text { sócios } \\
73 \text { contratados }\end{array}$ & - & $\begin{array}{l}\text { Total: } 65 \\
35 \text { sócios } \\
30 \text { contratados }\end{array}$ & $\begin{array}{l}\text { Viveram um período de queda na produção entre } \\
2013 \text { e } 2018 \text {. } 2019 \text { foi um ano de crescimento, mas } \\
\text { a produção foi bastante afetada pela pandemia de } \\
2020 \text {. }\end{array}$ \\
\hline
\end{tabular}




\begin{tabular}{|c|c|c|c|c|c|c|c|}
\hline \multirow{2}{*}{ Nome da empresa } & \multirow{2}{*}{ Estado } & \multirow{2}{*}{ Setor } & \multirow{2}{*}{$\begin{array}{c}\text { Ano do } \\
\text { início do } \\
\text { processo de } \\
\text { recuperação }\end{array}$} & \multicolumn{3}{|c|}{ Número de trabalhadores } & \multirow{2}{*}{ Produção } \\
\hline & & & & 2012 & 2017 & 2020 & \\
\hline \multicolumn{8}{|c|}{ Empresas que tiveram baixa na produção e/ou no número de trabalhadores nos últimos anos, porém mais recentemente parecem viver um momento estável } \\
\hline COOPEL & $\mathrm{AC}$ & Alimentação & 2004 & \begin{tabular}{|l|} 
Total: 75 \\
54 sócios \\
21 contratados
\end{tabular} & - & 25 & $\begin{array}{l}\text { Em } 2020 \text { disseram que a produção está estável nos } \\
\text { últimos anos/meses. }\end{array}$ \\
\hline UNIMÁQUINAS & SP & Metalúrgico & 2008 & 15 (todos sócios) & $\begin{array}{l}\text { Total: } 19 \\
7 \text { sócios } \\
12 \text { contratados }\end{array}$ & - & $\begin{array}{l}\text { De } 2012 \text { a } 2015 \text { ela aumentou bastante, porém en- } \\
\text { tre } 2015 \text { a } 2017 \text { teve uma queda significativa. Em } \\
2020 \text { disseram que a produção se manteve igual } \\
\text { nos últimos anos/meses. }\end{array}$ \\
\hline COOPECA & RS & Moveleiro & 2000 & $\begin{array}{l}\text { Total: } 80 \\
25 \text { sócios } \\
55 \text { contratados }\end{array}$ & $\begin{array}{l}\text { Total: } 59 \\
19 \text { sócios } \\
40 \text { contratados }\end{array}$ & $\begin{array}{l}\text { Total: } 57 \\
15 \text { sócios } \\
42 \text { contratados }\end{array}$ & $\begin{array}{l}\text { Em } 2017 \text { responderam que a produção vinha re- } \\
\text { duzindo nos últimos anos. Em } 2020 \text { disseram que } \\
\text { a produção foi reduzida por conta da pandemia. } \\
\text { Não sabemos como vinha no histórico anterior à } \\
\text { pandemia. }\end{array}$ \\
\hline COOTEGAL & RS & Têxtil & 1999 & $\begin{array}{l}\text { Total: } 123 \\
46 \text { sócios } \\
77 \text { contratados }\end{array}$ & $\begin{array}{l}\text { Total: } 160 \\
16 \text { sócios } \\
144 \text { contratados }\end{array}$ & $\begin{array}{l}\text { Total: } 74 \\
14 \text { sócios } \\
60 \text { contratados }\end{array}$ & $\begin{array}{l}\text { Em } 2017 \text { eles disseram que a produção tinha au- } \\
\text { mentado significativamente, praticamente dobra- } \\
\text { do. Em } 2020 \text { disseram que a produção foi afetada } \\
\text { pela pandemia e se mantém regular. }\end{array}$ \\
\hline COOPERTEXTIL & MG & Têxtil & 1997 & $\begin{array}{l}\text { Total: } 210 \\
147 \text { sócios } \\
63 \text { contratados }\end{array}$ & - & 130 (todos sócios) & $\begin{array}{l}\text { Viveram um período de queda na produção entre } \\
2013 \text { e } 2018 \text {. Os anos de } 2019 \text { e } 2020 \text { foram posi- } \\
\text { tivos, apesar da pandemia. }\end{array}$ \\
\hline EXATA & MG & Metalúrgico & 2001 & 7 (todos sócios) & - & 4 (todos sócios) & $\begin{array}{l}\text { Em } 2020 \text { contaram que o serviço tinha reduzido } \\
\text { nos últimos anos, mas agora vem aumentando no- } \\
\text { vamente. }\end{array}$ \\
\hline
\end{tabular}




\begin{tabular}{|c|c|c|c|c|c|c|c|}
\hline \multirow{2}{*}{ Nome da empresa } & \multirow{2}{*}{ Estado } & \multirow{2}{*}{ Setor } & \multirow{2}{*}{$\begin{array}{l}\text { Ano do } \\
\text { início do } \\
\text { processo de } \\
\text { recuperação }\end{array}$} & \multicolumn{3}{|c|}{ Número de trabalhadores } & \multirow{2}{*}{ Produção } \\
\hline & & & & 2012 & 2017 & 2020 & \\
\hline \multicolumn{8}{|c|}{ Empresas aparentemente em expansão } \\
\hline COOPERTRIM & MG & Metalúrgico & 2008 & 23 (todos sócios) & 40 (todos sócios) & 58 (todos sócios) & $\begin{array}{l}\text { De três anos para cá cresceu } 300 \% \text {. Em } 2017 \text { tam- } \\
\text { bém relataram que vinham crescendo. Tiveram } \\
\text { uma queda no início da pandemia, mas já retoma- } \\
\text { ram o patamar anterior. }\end{array}$ \\
\hline COOPERMAQ & $\mathrm{SC}$ & Metalúrgico & 2005 & $\begin{array}{l}\text { Total: } 70 \\
30 \text { sócios } \\
40 \text { contratados }\end{array}$ & 92 & $\begin{array}{l}\text { Total: } 107 \\
18 \text { sócios } \\
89 \text { contratados }\end{array}$ & $\begin{array}{l}\text { Em } 2017 \text { responderam que a produção vinha au- } \\
\text { mentando nos últimos anos. Em } 2020 \text { disseram } \\
\text { que a produção se manteve mais ou menos regular } \\
\text { nos últimos anos/meses. }\end{array}$ \\
\hline COOPERSHOES & RS & Calçados & 1998 & $\begin{array}{l}\text { Total: } 3328 \\
128 \text { sócios } \\
3200 \text { contratados }\end{array}$ & - & 4200 & $\begin{array}{l}\text { Hoje está produzindo em sua capacidade máxima } \\
\text { em suas cinco unidades fabris. }\end{array}$ \\
\hline \multicolumn{8}{|c|}{ Empresa parada, com dificuldade de retomada da produção } \\
\hline COMTERN & $\mathrm{RN}$ & Têxtil & 1982 & $\begin{array}{l}\text { Total: } 38 \\
32 \text { sócios } \\
6 \text { contratados }\end{array}$ & 26 & $\begin{array}{l}\text { Total: } 27 \\
19 \text { sócios } \\
8 \text { contratados }\end{array}$ & $\begin{array}{l}\text { Em } 2017 \text { responderam que a produção vinha re- } \\
\text { duzindo nos últimos anos. Em } 2020 \text { estava parada } \\
\text { e com grandes dificuldades de retomada por conta } \\
\text { da pandemia e de suas repercussões. }\end{array}$ \\
\hline
\end{tabular}

Fonte: Elaborado pelo autor. 
Embora seja importante considerar as limitações metodológicas, pela análise de um número restrito de casos e de informações obtidas por meio de contatos telefônicos breves, é possível, com base no Quadro 1, chegar a alguns apontamentos sobre a situação do conjunto das ERTs brasileiras mapeadas e acompanhadas pelo GPERT desde 2012.

Chama atenção que a maioria das empresas (14 dos 18 casos identificados no quadro) vive um momento de declínio na produção ou passou por isso nos últimos anos e está tentando se reerguer. O total de trabalhadores(as) envolvidos(as) em 13 desses 14 casos $^{15}$ era de 1.725 em 2012, e em 2020 reduziu para 969, ou seja, uma diminuição de quase 50\%. Além disso, pelo menos sete ${ }^{16}$ dessas 14 empresas perderam mais de $50 \%$ de seus sócios nesses oito anos.

Observando as características das três empresas identificadas no quadro como "aparentemente em expansão", uma delas quase triplicou o número de associados de 2012 para 2020. Nessa empresa, a Coopertrim, todos os(as) trabalhadores(as) são sócios (um relato sobre o caso foi incluído na seção seguinte deste artigo). As outras duas empresas que aparentam estar em expansão têm como característica comum o número de trabalhadores(as) associados(as) muito inferior ao número de contratados. Nelas, ainda, o número de associados(as) diminuiu ao longo do tempo, enquanto o de contratados aumentou. Ou seja, mesmo que a produção esteja em expansão nesse período de análise, há indicativos de que a participação de trabalhadores(as) e a luta pela autogestão podem não estar acompanhando essa expansão.

$\mathrm{Na}$ próxima seção será apresentado um pouco mais da história de quatro dessas empresas, em busca de outros elementos para análise.

\section{DIÁLOGOS COM ALGUMAS EXPERIÊNCIAS NO CENÁRIO DE CRISE PANDÊMICA}

Em busca de avançar na compreensão do quadro atual das ERTs brasileiras, sem recursos e condições ambientais/sanitárias para realizar uma pesquisa de campo nas empresas, elaborou-se um roteiro para entrevistas virtuais, com o objetivo de coletar informações gerais que permitissem analisar a situação dessas empresas no atual cenário político e econômico do país. Foram realizadas entrevistas qualitativas com quatro empresas recuperadas brasileiras, selecionadas por critérios relacionados à relevância, à diversidade e também à facilidade de contato e acesso aos casos. Considerou-se que essas histórias e relatos permitem uma visão parcial do fenômeno no país, pois tratam de casos singulares, mas ao mesmo tempo também apresentam dimensões e características recorrentes e bastante ilustrativas para avançar na compreensão das experiências no contexto atual, como será analisado adiante no artigo.

Seguem breves relatos das quatro empresas entrevistadas, que buscam apresentar reflexões sobre suas histórias e os desafios enfrentados em aproximadamente 20 anos de luta de seus(suas) trabalhadores(as). Busca-se ainda mostrar como essas empresas estão lidando com a pandemia e que demandas e proposições apresentam frente à crise atual. Cabe também apontar que tais relatos, além das informações coletadas nas entrevistas realizadas em 2020, também retomam informações de pesquisas anteriores empreendidas pelo GPERT, disponíveis em relatórios de projetos realizados e publicadas em 2013 e 2019.

\footnotetext{
${ }^{15}$ Para realizar a comparação, não foram considerados todos os 14 casos, pois não havia dados atuais do número de trabalhadores(as) em um deles.

${ }^{16}$ Cooperinca, Alumifer, Plastcooper, Coopeval, Coopel, Unimáquinas e Cootegal.
} 


\section{Coopertextil - Cooperativa de Produção Têxtil de Pará de Minas}

A entrevista na Coopertextil ocorreu em 18 de junho de 2020, por telefone, com um cooperado que trabalha na cooperativa desde o início do processo de recuperação pelos trabalhadores. Ele foi presidente da cooperativa em seus primeiros 12 anos, conciliando a função com a atividade no setor comercial da empresa. Hoje, ainda atua na área comercial e participa do Conselho Administrativo.

Essa recuperação surgiu do encerramento das atividades da antiga empresa Pará de Minas. Em 1997, os donos dessa empresa pediram concordata e sugeriram aos cerca de 500 trabalhadores(as), que ficariam desempregados(as) com o fechamento da empresa, que se organizassem para administrar a produção na forma de uma cooperativa. Foram os donos da empresa que indicaram um advogado para mediar esse processo e fizeram uma aproximação com a Organização das Cooperativas do Estado de Minas Gerais (OCEMG), entidade estadual ligada à Organização das Cooperativas do Brasil (OCB), para oferecer assessoria técnica e jurídica para o início do funcionamento da cooperativa.

Ela então arrendou o espaço da fábrica e, em um primeiro momento, conseguiu concessão para realizar as atividades de fiação, tecelagem e acabamento de tecidos. Cinco anos depois, no entanto, os antigos donos da empresa Pará de Minas, e ainda proprietários da fábrica, não renovaram o contrato de concessão sobre o direito relativo ao processo de acabamento, retomando o controle sobre essa etapa do processo, que segundo os trabalhadores é "a galinha dos ovos de ouro", ou seja, a etapa do processo que gera maior valor agregado.

Na primeira visita do grupo à Coopertextil, em 2012, os entrevistados disseram que o maquinário de fiação e tecelagem da fábrica era considerado semimoderno, combinando máquinas novas com outras mais antigas. A cooperativa, desde que formada, vinha investindo na compra de novos equipamentos automatizados, visando à modernização da produção com recursos próprios. Segundo o cooperado entrevistado em 2020, esse processo de investimento para modernização do maquinário não foi suficiente para uma renovação que permitisse boas condições de concorrência no mercado. Dessa forma, em 2015, ao perceber que o processo de fiação e tecelagem, operado com um maquinário de tecnologia defasada em relação ao mercado, não vinha gerando um retorno financeiro suficiente para a manutenção da cooperativa, os(as) trabalhadores(as) investiram na retomada do processo de acabamento. Um ano depois, eles decidiram desativar as atividades de fiação e tecelagem, e atualmente permanecem somente com o acabamento.

No momento da formação da cooperativa, eram cerca de 200 trabalhadores(as) organizados. Segundo relatos do entrevistado, a cooperativa chegou a ter até 400 trabalhadores(as). Em alguns momentos, ela teve trabalhadores(as) contratados(as), uma vez que adotava uma forma de período probatório de dois anos, na qual novos(as) trabalhadores(as) eram admitidos pela CLT e, passados dois anos de experiência, se tornavam cooperados(as). Em 2020, no entanto, os(as) 130 trabalhadores(as) da empresa são cooperados(as), não havendo nenhum(a) contratado(a). Ele conta que o número de trabalhadores(as) na empresa teve uma redução significativa quando se encerraram os processos de fiação e tecelagem, há quatro anos.

Destoando da realidade da maioria das ERTs brasileiras, na Coopertextil, do total de 130 trabalhadores(as), 40\% são mulheres. O trabalhador entrevistado na pesquisa conta que antes do encerramento da fiação e da tecelagem elas representavam cerca de $70 \%$ do total de trabalhadores(as) da empresa, mas como o acabamento demandaria mais homens na produção, houve a redução. Todavia, ele diz que na Coopertextil algumas mulheres ocupam funções que em outras indústrias similares são geralmente ocupadas por homens. Ao ser perguntado 
sobre a participação das mulheres na gestão da empresa, ele acrescenta que as mulheres têm participação ativa no conselho administrativo, e que hoje a vice-presidente é uma mulher.

O entrevistado dizainda que "a mão deobra está ficando velha", poisos(as) trabalhadores(as) envelhecem na cooperativa e só saem quando se aposentam ou morrem. Dessa forma, há poucos jovens na empresa, e em busca de modificar esse quadro, sempre que sai um(a) trabalhador(a) mais velho(a), procuram substituir por outro(a) de mais ou menos 20 anos. Acrescenta também que os(as) novos(as) trabalhadores(as) entram direto como cooperados na atualidade.

O momento de pandemia gerado pela covid-19 foi marcado inicialmente pela paralisação das atividades da fábrica, devido à retirada dos pedidos dos clientes. Com isso, foram forçados a tirar férias, mas logo depois conseguiram redirecionar o tecido disponível em estoque para a fabricação de máscaras. De volta ao trabalho em menos de uma semana, a fábrica voltou a operar em sua capacidade máxima. No momento da entrevista, ela funcionava em dois turnos de produção, de nove horas, completando uma jornada de 5 a 23 horas.

O cooperado diz que o ano de 2019 foi muito positivo para a empresa. Segundo ele, o melhor dos últimos 10 anos. Quando da visita à empresa em 2012, ela operava com cerca de $70 \%$ de sua capacidade instalada. Segundo os entrevistados na época, a empresa viveu um bom momento nos anos 2000/2001, chegando a operar com 100\% de sua capacidade. Depois houve um período difícil, por volta de 2010/2011, quando a produção caiu para a metade da capacidade da fábrica. Em 2012, ela vinha se recuperando da fase difícil. De acordo com a última entrevista (2020), o período de 2013 a 2018 também foi delicado no que diz respeito à saúde econômica e produtiva da empresa. $\mathrm{Na}$ atualidade, o entrevistado se mostrou animado com as perspectivas de crescimento das atividades.

O processo de formação da cooperativa não gerou mudanças profundas na forma de organização da empresa. A criação da assembleia, do conselho administrativo e do conselho fiscal foi a mudança mais marcante, segundo os entrevistados. No nível intermediário, entre o conselho e o chão de fábrica, onde atuavam os antigos encarregados de produção, passaram a existir os coordenadores de setores. O conselho administrativo é composto por quatro pessoas e é eleito a cada três anos. Em visita à empresa em 2012, foi relatado que esta tinha dificuldade de renovação do conselho por falta de interesse dos(as) trabalhadores(as) em participar do espaço. O último entrevistado em 2020, no entanto, diz que nos anos posteriores fizeram um esforço e conseguiram de fato renovar. A presidência da cooperativa, que foi ocupada pelo entrevistado nos primeiros 12 anos, nos últimos seis anos está a cargo de um antigo pedreiro da fábrica. No agendamento dessa entrevista, no entanto, a pessoa indicada para conversar sobre a empresa foi o mesmo cooperado, ex-presidente da cooperativa.

As assembleias na Coopertextil são realizadas anualmente e, ao que parece, não são de fato um espaço de participação ampliada e tomada de decisões estratégicas. Elas servem principalmente para prestação de contas e formalização da entrada de novos cooperados. No relato do entrevistado, ele conta que existe um conselho disciplinar, que não nos foi apresentado na ocasião de nossa visita em 2012. Ele é composto por seis pessoas, eleito anualmente e, segundo ele, quase sempre $100 \%$ renovado. De acordo com o entrevistado, essa renovação completa também costuma ocorrer no conselho fiscal, que tem eleições anuais.

Em 2012, foi citada uma série de cursos e treinamentos que eram oferecidos para os trabalhadores(as) e custeados pela cooperativa. Os cursos eram voltados quase sempre para questões técnicas, como tornearia, caldeiraria e elétrica. Mas, segundo os entrevistados 
da época, não eram muitos os(as) trabalhadores(as) que se interessavam. Eles disseram: "são sempre os mesmos trabalhadores que se interessam pelos cursos, assim estes criam um maior compromisso para com a cooperativa, além de ter uma melhor percepção de seu trabalho".

A cooperativa não tem e nunca teve como política a retirada igualitária para o conjunto de trabalhadores(as). Os valores de retirada variam de acordo com a função ocupada, tendo em 2020 o valor mínimo de cerca de $\mathrm{R} \$ 1.600$ e máximo por volta de $\mathrm{R} \$ 7.000$. Em 2012, a retirada mínima era da ordem de $\mathrm{R} \$ 800$, e a máxima, da ordem de $\mathrm{R} \$ 5.000$. Parece, portanto, que a diferença entre a menor e a maior remuneração foi reduzida. Sobre o tema, o entrevistado diz que a cooperativa oferece uma remuneração que tem como referência o mercado em seu setor de atuação, pagando, no entanto, acima do patamar da iniciativa privada na região. Segundo ele, ninguém sai da cooperativa por causa disso. Por fim, no que se refere aos rendimentos dos trabalhadores(as), ele afirma que a distribuição das sobras é igual para todos. A cooperativa oferece ainda assistência médica aos cooperados(as), vale-mercado que corresponde a $25 \%$ da remuneração e uma cesta básica, que, de acordo com o cooperado, equivale ao dobro de uma cesta básica padrão.

Apesar das dificuldades em ampliar a participação dos(as) trabalhadores(as), reconhecidas e problematizadas pelos entrevistados tanto em 2012 como em 2020, eles dizem que ainda assim se consideram uma empresa de autogestão, "pois não há patrão" e "se produzir mais, todos ganham" (entrevista de 2012). Segundo relatos da época, "a gente trabalha para a gente, porém nem todos têm consciência disso". O cooperado, na entrevista realizada em 2020, diz que o cooperativismo precisa ser mais incentivado no país, e que "devia ter no congresso uma bancada cooperativista". Para ele, o cooperativismo representa distribuição de renda e maior participação das pessoas no trabalho, e com maior participação mudam seu comportamento e sua relação com o trabalho.

Não foi observado, no entanto, entre os entrevistados de 2012 e de 2020 um engajamento da cooperativa ou de seus associados em ampliar a luta pela autogestão para além dos muros da fábrica. A Coopertextil participa da Justa Trama, uma cadeia produtiva formada por empreendimentos de Economia Solidária que envolve desde o plantio do algodão agroecológico até a comercialização de peças de confecção produzidas com esse insumo ${ }^{17}$, e também da Unisol Brasil, mas essa participação parece bastante esporádica e de pouca influência no cotidiano da cooperativa e de seus(suas) trabalhadores(as). As relações da cooperativa com a comunidade no entorno parecem fracas, limitando-se a doações pontuais de tecido, como citado pelo entrevistado, para a confecção de máscaras para a comunidade ou de cortinas para escolas públicas do município.

Antes de encerrar a conversa com o cooperado, foi perguntado se ele via perspectivas para a retomada do fenômeno de recuperação de empresas com alguma similaridade em relação ao que ocorreu no final dos anos 1990 no Brasil. Ele disse que muitas indústrias têxteis têm enfrentado dificuldades econômicas no momento atual e citou duas grandes empresas do setor situadas no estado de São Paulo que, juntas, demitiram cerca de 3.000 pessoas no período de pandemia. Todavia, não se mostrou otimista quanto à possibilidade de organização dos(as) trabalhadores(as) para a retomada da produção, caso essas empresas venham a fechar. Mas disse, por fim: "é um caminho, é um caminho sim".

\footnotetext{
${ }^{17}$ Para saber mais sobre o tema, ver: https://www.justatrama.com.br/sobre-nos/. Acesso em: 21 dez. 2020.
} 


\section{Uniforja - Cooperativa Central de Produção Industrial de Trabalhadores em Metalurgia}

Em uma área central do município de Diadema, na região metropolitana de São Paulo, localiza-se a Uniforja. Com histórica atuação econômica voltada à indústria, compondo o ABCD Paulista, Diadema foi um bairro industrial de São Bernardo do Campo, independente em 1959. Criada pelos empregados da antiga Conforja S/A (empresa metalúrgica fundada em 1954), então em processo de falência, a Uniforja tem origem na formação de quatro cooperativas: Coopertratt, Cooperlafe, Coopercon e Cooperfor, em 1997 e 1998.

A Uniforja é, possivelmente, um dos casos de recuperação de empresa por trabalhadores mais conhecidos e importantes do país na atualidade, por sua dimensão, longevidade, histórico com o Sindicato dos Metalúrgicos do $\mathrm{ABC}$ e atuação na criação e no apoio à Unisol Brasil e a outros empreendimentos solidários. Por esses motivos, ao longo de sua trajetória pesquisadores(as) do grupo fizeram diversos contatos e visitas a essa cooperativa.

Conforme relatos coletados nessas visitas sobre sua história, dentre os 600 trabalhadores da empresa anterior, 320 decidiram permanecer, subdividindo a empresa em quatro unidades especializadas: tratamento térmico e transformação de metais; laminação de anéis e forjados especiais; fabricação de curvas e conexões tubulares em aço carbono, baixa liga e inox; fabricação de forjados automotivos e flanges. Essas unidades deram origem às cooperativas citadas, que compartilham a mesma sede $\left(\mathrm{de} 65 \mathrm{mil} \mathrm{m}^{2}\right)$ e trabalham de forma integrada no chão de fábrica. Em 2000, a Uniforja foi criada para integrar essas cooperativas, com o objetivo de dar suporte logístico nas áreas de gestão administrativa, aquisição de insumos e matérias-primas, venda de produtos acabados e beneficiamentos, serviços de manutenção, engenharia, método de produção e desenvolvimento tecnológico, qualificação profissional, desenvolvimento de novos produtos etc. Em 2005 a Coopercon foi fechada, e seus cooperados e sua produção foram subdivididos e integrados às outras três cooperativas, sem que algum trabalhador fosse demitido, como destacado em entrevistas com os trabalhadores (SÍGOLO, 2007).

Nos anos seguintes, a Uniforja tornou-se a maior fabricante de flanges e conexões de aço forjado da América Latina (com certificações ISO 9001 e ISO/TS 16949, automotiva) e obteve dois empréstimos junto ao Banco Nacional de Desenvolvimento Econômico e Social (BNDES), constituindo uma exceção entre os casos de recuperações no Brasil.

Com o primeiro empréstimo, ela arrematou em leilão, junto à massa falida da antiga empresa, as instalações e os maquinários. Em 2006, em pesquisa de campo na empresa, Sígolo (2007) relata que havia 532 trabalhadores(as) na Uniforja, 287 cooperados e 245 funcionários celetistas. Estes últimos, naquela época, recebiam formação em cooperativismo e, após três anos, em comum acordo, se tornavam cooperados. Para isso, utilizavam $80 \%$ da rescisão para pagar a primeira parcela da cota-parte do capital social (de 50 mil reais, naquele momento), que podia ser integralizada em até 20 anos, com descontos de 10 a $20 \%$ da retirada do cooperado. Desde o início, os serviços de limpeza, segurança e do refeitório são terceirizados. Cabe ressaltar que sempre houve um número bastante reduzido de mulheres na empresa (cerca de 10\%).

A Uniforja declara em seu site que "trabalha para ser espelho de autogestão democrática no Brasil, líder no mercado interno e reconhecida internacionalmente" (UNIFORJA, 2020). Com relação a sua gestão, segundo as pesquisas, a Uniforja é uma central de cooperativas afiliadas que se comunica com estas por seus conselhos de administração, sendo que as cooperativas realizam assembleias mensais e os membros de seus conselhos participam das assembleias da Uniforja (Assembleia Geral Ordinária - AGO, Assembleia Extraordinária da Lei n. ${ }^{\circ} 12.690$ e assembleias sob demanda). 
A cada três anos há eleições para o conselho administrativo nas cooperativas e a cada quatro anos na Uniforja, sendo que seu conselho é composto por oito membros, com representantes das cooperativas afiliadas. Nas diversas entrevistas realizadas com a empresa, os trabalhadores relataram que há elevada participação dos cooperados nas assembleias. Com relação aos funcionários celetistas, mencionaram reuniões que ocorrem junto ao sindicato para tratar de acordos coletivos, banco de horas ou demandas específicas, bem como de direitos e esclarecimentos, além de realizarem reuniões nos departamentos, com coordenadores.

Sobre as remunerações, nas pesquisas realizadas em 2006 foi relatado que eram de 15 a $20 \%$ superiores às do mercado, e a variação entre a maior e a menor retirada na proporção de 1 para 7, conforme estabelecia o estatuto da cooperativa. Nesse momento se verificava uma fase de expansão econômica, sendo que os produtos da Uniforja eram majoritariamente vendidos no mercado nacional, feitos sob encomenda, em parte destinados à Petrobras (com seus técnicos fiscalizando a produção). Entre as dificuldades do período, mencionaram que o monopólio na extração de minério no Brasil dificultava a compra de matéria-prima nacional, e que os insumos advinham principalmente da Bélgica e da China.

Ao longo da última década, o grupo de pesquisa manteve contato com a empresa e realizou outras visitas a ela. Em 2012, no primeiro mapeamento de casos no Brasil, identificouse uma pequena redução no número de trabalhadores(as), totalizando 497, e um aumento no número de cooperados(as), somando 295 sócios(as). Todavia, na atualização de dados realizada em 2017, verificou-se que havia ocorrido uma importante queda no número de trabalhadores(as), que passaram a somar 322, incluindo a queda do número de cooperados(as), que totalizavam 234, e uma importante redução do número de celetistas, que passaram a ser de 88 contratados(as). Nesse momento, em 2017, a empresa relatou uma grave redução da produção, especialmente a partir da crise de 2008.

Em meio à pandemia, em 8 de julho de 2020 foi feito um novo contato com a empresa e uma entrevista com um cooperado, membro desde sua fundação. Conforme ele relata, a empresa seguia funcionando, com trabalhadores(as) do grupo de risco afastados, recebendo $100 \%$ das retiradas, havia três meses. Na data da entrevista, estavam avaliando uma readequação e uma possível redução das retiradas devido ao aprofundamento da crise. Dentre as propostas, estavam avaliando criar um banco de horas para uma futura compensação. Na produção, ele informa que estão seguindo os protocolos de proteção e que no setor administrativo está sendo realizado também o chamado home office.

Cabe destacar que na ocasião da entrevista havia 100 cooperados(as) e sete celetistas afastados(as) por serem do grupo de risco, fato bastante recorrente em empresas recuperadas mais antigas. O entrevistado destacou que grande parte dos(as) sócios(as) cooperados(as) são maiores de 60 anos e que os(as) contratados(as), em geral, são mais jovens. A média de idade dos(as) trabalhadores(as) na ocasião, conforme informou, estava em torno de 50 anos.

Em julho de2020, a empresa totalizava 293 trabalhadores(as), sendo 213 cooperados(as), considerando as três cooperativas afiliadas, e 80 funcionários(as) celetistas. Em contraste com os dados citados de 2006, verificou-se que nos últimos 14 anos houve uma importante redução do número de trabalhadores(as) com a saída de vários funcionários(as) celetistas e também cooperados(as). $\mathrm{O}$ entrevistado relata que criaram uma espécie de pacote para o desligamento de cooperados(as). Outra mudança relevante é o fato de que havia sido suspensa, há alguns anos, a entrada de novos(as) sócios(as) pelo contexto de crise, pois consideram elevado o número de cooperados(as) da empresa. 
Avaliando a produção, nessa entrevista o cooperado reafirmou a considerável redução ocorrida na última década. Desde a crise de 2008, a empresa teve uma perda de cerca de $40 \%$ da produção e tem hoje capacidade produtiva ociosa, com retrocesso de demanda. Segundo avalia, este decorre da concorrência com a China, da crise econômica e, recentemente, da pandemia, sendo que a queda na produção da Uniforja é expressão do processo de desindustrialização do país, que se aprofundou na última década, com a falta de políticas voltadas a estimular a produção e a indústria nacional. Como destaca, a empresa sobrevive pela própria expertise, pois não tem acesso adequado a crédito. Sem contar mais com o BNDES, a Uniforja tampouco se encaixa nos pacotes de incentivo da crise, pelo faturamento alto da empresa, que segundo o cooperado deveria ser considerado em conjunto com o fato de ser uma empresa social, com foco em manter seus(suas) trabalhadores(as).

O entrevistado relata que desde o início da pandemia não fizeram assembleias, mas criaram alternativas de comunicação virtuais. Sobre a questão, ele destaca uma demanda grande de formação/treinamento dos(as) trabalhadores(as) para lidar com as novas tecnologias informacionais ${ }^{18}$. Com relação a retiradas, apontam que atualmente a empresa segue valores do mercado para as diferentes funções, todavia, destaca que as sobras ainda são distribuídas igualmente entre cooperados(as) - assim como prejuízos, conforme destaca. No entanto, aponta que a diferença entre as retiradas não ultrapassa cinco vezes. Explica também que parte das sobras é reinvestida na empresa e que há hoje uma diferença de aproximadamente 25 mil reais entre a maior e a menor capitalização, o que não interfere nas assembleias, que funcionam com base no princípio de "cada cabeça um voto".

As visitas realizadas à Uniforja, desde o início, ocorreram por contato com a Unisol Brasil (União de Cooperativas ligada ao Sindicado dos Metalúrgicos do ABC), da qual a empresa é membro-fundadora. A entidade, criada em 2000, visa atuar na articulação política, na intermediação com o Estado, no apoio técnico a empreendimentos e na formação de trabalhadores(as), e teve por vários anos um cooperado da Uniforja cedido e remunerado pela empresa como presidente. Via Unisol Brasil, a empresa apoiou outros empreendimentos de autogestão, participou de espaços políticos e do movimento de Economia Solidária.

$\mathrm{Na}$ última entrevista, todavia, a avaliação é de que esse projeto está enfraquecido na atualidade e não há um coletivo unido na Unisol, por exemplo, com consensos jurídico e contábil, compras conjuntas, fóruns de trocas de experiências etc. Citando a Organização Cooperativista do Brasil (OCB), única organização cooperativista reconhecida pelo governo desde 1971 (fato que não foi modificado nos governos do PT, como destaca), o entrevistado destaca que toda cooperativa é obrigada a contribuir com o Serviço Nacional de Aprendizagem do Cooperativismo (SESCOOP), fundo de apoio a cooperativas, embora este seja acessado apenas pela OCB e suas associadas.

Como relata, a Uniforja contribui com mais de 2 milhões de reais a este fundo, sem ter conseguido acessar qualquer apoio por não ser filiada à $\mathrm{OCB}$, a qual avalia não ser uma alternativa para cooperativas sociais, inclusive por não atuar no ramo da metalurgia. Em contraste, ele destaca que muitas recuperações de empresas em autogestão e criação de cooperativas sociais ocorreram pela atuação do Sindicato dos Metalúrgicos do ABC e, posteriormente, da Unisol Brasil, sem acesso a esses recursos. Com isso, reforça que esta entidade sobrevive por resistência.

\footnotetext{
${ }^{18}$ Essa demanda também surgiu na conversa com a empresa Alumifer, e acredita-se que seja comum a outras empresas do universo da pesquisa.
} 
Diante da crise atual, pondera ser possível e necessário uma retomada desse projeto, com maior comunicação entre empreendimentos associados. Para isso, conta que recentemente criaram grupos virtuais de afiliadas por ramo de atividade, para avançar no debate sobre parcerias e apoios mútuos. Em relação às universidades, apesar de receberem frequentemente pesquisadores(as), destaca que não têm projeto ou parceria com elas, inclusive pela falta de políticas. Todavia, conta que recentemente foi criado um câmpus da Universidade Federal de São Paulo (UNIFESP) em área contígua à empresa, ocupando parte da antiga Conforja, o que fez da Uniforja possivelmente a única empresa com uma universidade "dentro" dela, como ressalta.

Após 20 anos de existência da empresa, em 2020 o entrevistado colocou em questão a expressão "empresas recuperadas", apontando que a Uniforja já se recuperou e seria mais adequado denominá-la hoje de "empresa de autogestão", por ser uma referência dentro e fora do Brasil em seu ramo de atuação, mesmo usando equipamentos de 40 anos. Ele também ponderou sobre a forma jurídica cooperativa, restrita à lei de 1971, inadequada em muitos aspectos às empresas de autogestão. Destacando perspectivas futuras da empresa no ramo da energia eólica, além do automotivo, o entrevistado reforçou a necessidade de atualizar a fábrica tecnologicamente, mas avaliou que falta um olhar específico, políticas públicas e incentivos adequados às indústrias e empresas sociais no Brasil. Finalmente, o diálogo reforçou a percepção de que a recuperação de empresas por trabalhadores(as) está bastante ausente e distante dos debates e do próprio imaginário de lutas das entidades sindicais e das organizações e dos movimentos das classes trabalhadores e populares do país na atualidade.

Expressando características predominantes do fenômeno no país, como pertencer ao ramo da metalurgia, a presença importante de contratados(as), a forma jurídica cooperativa, a localização na Região Sudeste etc., a experiência da Uniforja certamente suscita reflexões fundamentais sobre as recuperações de empresas e a autogestão no Brasil atual.

\section{Metalcoop - Cooperativa de Produção Industrial de Trabalhadores em Conformação de Metais}

A Metalcoop surgiu da falência da fábrica Picchi, empresa do setor metalmecânico que trabalhava com forjaria, vendendo autopeças e itens para maquinários agrícolas. A fábrica começou a enfrentar problemas financeiros sérios em 1998, com atrasos nos salários, na liberação das férias e no pagamento do FGTS, o que tornou a gestão da fábrica insustentável. Em 2001, o clima de disputas com a direção foi tão intenso que os(as) trabalhadores(as) ficaram 60 dias em greve (ESTEVES, 2010).

Em 2001, com a crise na Picchi, os(as) trabalhadores(as) começaram a criar comissões de fábrica para gerir a produção e gerar faturamento para pagar seus salários. Foram criadas três comissões de fábricas, todavia, a situação não melhorava. Em 2002, o diretor-geral da Picchi foi afastado, em decorrência de um mandado de prisão, e em julho deste ano os(as) trabalhadores(as) se reuniram no sindicato e decidiram assumir a gestão da fábrica (ESTEVES, 2010). A decisão inicial era criar um tipo de cogestão, mas como a proposta foi vista com total descrédito pela administração da empresa, os(as) trabalhadores(as) mudaram a estratégia para a autogestão. A empresa então demitiu todos(as) os(as) trabalhadores(as) e o maquinário e as instalações da massa falida foram usados como verbas rescisórias com a anuência do sindicato. $\mathrm{Na}$ época, havia 121 trabalhadores(as) da antiga empresa, e a Metalcoop foi fundada em agosto de 2002, com 89 trabalhadores(as) cooperados(as) (ESTEVES, 2010). 
O GPERT esteve na Metalcoop em 2012, ocasião em que a fábrica havia se tornado famosa por ter conseguido 6,6 milhões de reais do BNDES. A empresa também era conhecida por conta da atuação de seu presidente, como coordenador do sudeste da Unisol Brasil, sendo um antigo parceiro nas pesquisas do grupo. Nesse ano, a cooperativa tinha 124 trabalhadores(as), sendo 51 sócios(as) e 73 contratados(as). Nesta visita, registrou-se que a empresa tinha diferenças de retirada entre os(as) cooperados(as) de no máximo 1 para 5 , variando de 2.400 a 10.000 reais. Considerando os(as) contratados(as), a diferença chegava a 1 para 10. Segundo os relatos coletados, a fábrica mantinha boas remunerações em relação ao mercado, constituindo uma empresa disputada para se trabalhar na região.

Essas boas condições de trabalho foram reforçadas por pesquisa realizada em 2017, em relação às condições de saúde e segurança da fábrica (AZEVEDO, SOUZA; GONÇALVES FILHO, 2019). A questão da saúde e da segurança do trabalho nas empresas recuperadas pelos trabalhadores(as) no Brasil merece destaque, conforme já apontamos em trabalhos anteriores (HENRIQUES et al., 2013; ARAÚJO et al., 2019). As conquistas nesse sentido chamaram atenção do grupo de pesquisa em quase todas as visitas às ERTs no país, e foi tema aprofundado em alguns estudos anteriores (ARAÚJO, 2016).

Em 2020, o grupo procurou mais uma vez a Metalcoop e conversou com o mesmo entrevistado, hoje seu vice-presidente. A entrevista teve o intuito de entender como a Metalcoop estava enfrentando a crise da pandemia e ocorreu também por chamada de vídeo. Com relação ao estado atual da cooperativa, o entrevistado relatou que esta viveu seu ápice com mais de 100 trabalhadores(as) em período próximo a 2012, mas avalia que principalmente após a queda do governo Dilma seguiu em crise. Segundo ele, "começamos com 87 cooperados e hoje só temos 35", sendo que todas as saídas ocorreram por aposentadoria. Com isso, nesse momento, a empresa conta com 65 trabalhadores(as), 35 sócios(as) e 30 contratados(as).

Segundo o entrevistado, em 2018, após um período de grave queda, o faturamento mensal da empresa estava em um milhão de reais ${ }^{19}$. Todavia, em 2019, havia alcançando 1,6 milhão. Mas ele relata que o contexto da pandemia tem tornado as coisas mais difíceis e que o faturamento reduziu a dois terços, cerca de 900 mil reais mensais. Apesar do difícil cenário, o entrevistado mencionou que não houve redução no número de trabalhadores(as). Destacou também que apenas dois colaboradores, com problemas de saúde, foram afastados para se proteger do risco da Covid-19.

A pandemia trouxe uma redução dos pedidos e do faturamento, e para manter o contingente de trabalhadores/as nesse momento, ele relata que a empresa fez uma análise do que causaria menor prejuízo aos/às trabalhadores/as. Com isso, eles decidiram reduzir o salário dos/as empregados/as em 50\% durante 3 meses, e compor com o valor repassado pelo governo. Ele destaca que com este auxílio a redução real do salário recebido pelos contratados foi de apenas 5-6\%. Com relação aos/às cooperados/as, decidiram por uma redução de $25 \%$ das retiradas, por tempo indeterminado, e neste caso sem nenhum valor a mais. Essa decisão foi tomada em assembleia, que segundo o entrevistado continuam sendo realizadas com frequência mensal e contam com a participação de cerca de $70 \%$ dos/as cooperados/as. Os/As contratados/as não participam das assembleias para tomadas de decisão, com eles são feitas reuniões de esclarecimentos.

Outro dado relevante mencionado na entrevista refere-se a certa redução das diferenças salariais com o passar dos anos. Segundo o entrevistado, os/as cooperados/as ganham hoje em torno de 3.500 reais, sendo que as maiores remunerações brutas estão em torno de 11.000 reais.

${ }^{19}$ Essa crise também é comentada na pesquisa realizada em 2017 por Azevedo, Souza e Gonçalves Filho (2019). 
Entre os/as empregados/as, os salários variam entre 2.000 e 3.500 reais, valores brutos que são somados à assistência médica, transporte e alimentação.

Alguns outros elementos foram identificados na entrevista. Com relação à participação das mulheres na cooperativa, percebe-se que não há mudanças em relação ao comportamento do setor metalúrgico. Na cooperativa, há apenas 3 mulheres, sendo que todas estão no setor administrativo e não há trabalhadoras na produção.

Com relação à recuperação de novas empresas, o entrevistado menciona que o momento é muito delicado e que será preciso no futuro lutar pela criação de novos postos de trabalho. Contudo, pondera que o mercado é muito cruel:

Eles vão começar a demitir trabalhadores e o movimento sindical tem que estar se organizando para apoiar essas experiências e ações nesse sentido. E os trabalhadores das cooperativas já organizadas também. Precisamos nos preparar para esse momento, pois tudo indica que vá ser necessário, pois a economia não vai aguentar (...). Então é possível que a gente precise pensar a recuperação de novas empresas.

\section{Coopertrim - Cooperativa de Trabalho Industrial em Metalurgia de Raul Soares/MG}

A entrevista com a Coopertrim foi realizada em 25 de junho de 2020, por telefone, com o atual presidente da cooperativa, ex-funcionário da empresa falida e que trabalha na cooperativa desde o início.

No primeiro contato que o GPERT fez com a cooperativa, em 2012, na realização do primeiro mapeamento, encontrou trabalhadores(as) ansiosos(as) pelo início da produção, que se iniciaria naquele mesmo ano, após um longo processo judicial. Na ocasião, portanto, não foram obtidas informações sobre processo produtivo, faturamento, organização do trabalho, entre outros pontos abordados na pesquisa. Eles(as) estavam na linha de largada da cooperativa, embora muita luta já tivesse ocorrido até ali.

A empresa da qual a cooperativa se originou, a Metalúrgica São Sebastião, iniciou suas atividades em 1946. Ela chegou a ter 600 trabalhadores(as) em seu auge, em 2000, porém, em 2008, entrou em processo de falência e esse número de trabalhadores(as) foi reduzido para 200. Nesse momento, os(as) trabalhadores(as) iniciaram a luta pela recuperação da empresa, que foi formalizada como cooperativa em 2009, com a criação da Coopertrim. Todavia, os(as) trabalhadores(as) somente conseguiram entrar na fábrica no final de 2011, pois esta se manteve lacrada pela justiça.

A rede de apoio que se formou em prol da recuperação da empresa foi fundamental para a preparação da cooperativa para a nova fase de produção, baseada no cooperativismo e na autogestão. A Unisol Brasil, entidades sindicais, a Universidade Federal de Viçosa, alguns políticos e a própria comunidade do entorno auxiliaram de diversas maneiras, por meio de orientação técnica e legal para a formação da cooperativa; formações sobre cooperativismo e sistemas de gestão; compra de insumos; recuperação do espaço físico, das máquinas e de outras adequações. Um apoio especial, que marca muito a fala do entrevistado, foi o da Uniforja, outra ERT do mesmo ramo, referida anteriormente nesse artigo. Segundo o relato, essa empresa também colaborou com cursos, formação sobre cooperativismo e gerenciamento e foi essencial no apoio financeiro para a primeira compra de material da cooperativa e, posteriormente, na compra conjunta de aço. Nas palavras do entrevistado: "Aqui para a gente primeiro é Deus, depois é a Uniforja, e depois somos nós, os trabalhadores". 
Atualmente, não contam mais com essa rede de apoio de maneira articulada. Recebem apoios pontuais de vereadores locais e de um professor que recentemente se afastou por um problema sério de saúde. Relatam que enfrentam dificuldades de acesso a linhas de crédito e também criticam a falta de políticas específicas para a Economia Solidária. Apesar disso, a Coopertrim está na contramão da maioria das experiências de ERTs pesquisadas, uma vez que ela só cresceu desde seu início. Essa condição também destoa do cenário das empresas de forjaria. Como relata o entrevistado, várias delas vêm fechando na região da Coopertrim, mesmo antes do contexto da pandemia. Esse diagnóstico já havia sido constatado na atualização de dados sobre as ERTs, realizada em 2017 pelo grupo. Na ocasião, verificou-se que a Coopertrim vinha expandindo a linha de produtos para atender as demandas e incorporar os clientes dessas outras empresas em crise.

Para a cooperativa, as vendas estão se mantendo, mesmo nesse período de intensificação da crise econômica. Segundo o entrevistado, a empresa retomou o equilíbrio rapidamente depois dos primeiros efeitos da pandemia e relatou que estava com muito trabalho. A empresa produz ferramentas agrícolas, com um catálogo atual de 240 produtos diferentes, todos forjados. Ele aponta que o maquinário é antigo, mas produtivo, devido ao fato de a cooperativa ter equipe própria de manutenção, que permite a melhoria das máquinas, pois conforme avalia: "sem uma manutenção forte para as máquinas, as forjarias fecham".

No primeiro mapeamento de 2012, o quadro de sócios(as) cooperados(as) era composto pelos(as) mesmos(as) 23 trabalhadores(as) fundadores(as) da cooperativa e antigos(as) funcionários(as) da empresa falida. Na atualização de 2017, o número de sócios(as) trabalhadores(as) aumentou para 40, e em 2020, para 58, com a expectativa de crescimento em breve. Com a ampliação da demanda de trabalho, a cooperativa vem chamando ex-funcionários(as) da antiga empresa falida para compor o quadro de sócios(as). Como a aposentadoria nesse ramo acontece com 25 anos de trabalho, por ser considerado insalubre, muitos trabalhadores(as) que compunham o quadro original da cooperativa já se aposentaram. No ano em que as atividades produtivas começaram, dois deles já estavam prestes a se aposentar. Por causa disso, a cooperativa tem um projeto de renovação: incorporar pessoas mais novas para que aprendam o ofício com os que ainda não se aposentaram. Apenas duas mulheres compõem o quadro de cooperados(as) e trabalham no escritório.

As adequações e os pequenos investimentos que a cooperativa fez, inclusive para a expansão da linha de produtos, foi com recursos próprios. O entrevistado relatou que já tiveram de pedir um empréstimo por não conseguirem atingir o ponto de equilíbrio e que ainda estão terminando de pagá-lo. Como a cooperativa opera muito próximo ao ponto de equilíbrio, não consegue planejar benefícios e auxílios para os(as) trabalhadores(as). Apesar disso, segundo o entrevistado, o salário da Coopertrim está melhor se comparado a postos de trabalho similares na região. A maior diferença salarial da cooperativa é de 500 reais, sendo que as remunerações variam de 1500 a 2000 reais.

O plano da Coopertrim no momento é aumentar o faturamento, conforme destaca o cooperado. Seu principal objetivo é acessar crédito para comprar a massa falida, uma vez que a cooperativa é arrendatária desta e sonha em comprá-la um dia. Porém, há um sentimento dúbio, pois à medida que empresa melhora (o que é bom), a massa falida também valoriza, exigindo uma despesa cada vez maior para adquiri-la. 
Para uma breve síntese desses quatro relatos, buscando identificar elementos em comum e ilustrativos do fenômeno na atualidade, destacam-se no Quadro 2 alguns pontos presentes nos casos.

\section{QUADRO 2 - BREVE SÍNTESE COMPARATIVA ENTRE OS CASOS}

\begin{tabular}{|c|c|c|c|c|}
\hline & COOPERTEXTIL & UNIFORJA & METALCOOP & COOPERTRIM \\
\hline $\begin{array}{l}\text { Processo inicial de } \\
\text { recuperação }\end{array}$ & $\begin{array}{l}\text { Mediado pelo antigo } \\
\text { dono. }\end{array}$ & $\begin{array}{l}\text { Conflito com antigo } \\
\text { dono. }\end{array}$ & $\begin{array}{l}\text { Conflito com antigo } \\
\text { dono. }\end{array}$ & $\begin{array}{l}\text { Conflito com antigo } \\
\text { dono. }\end{array}$ \\
\hline $\begin{array}{l}\text { Articulação entre } \\
\text { empresas de } \\
\text { autogestão }\end{array}$ & $\begin{array}{l}\text { Relação distante com } \\
\text { UNISOL e Justatrama. }\end{array}$ & $\begin{array}{l}\text { Relação forte com } \\
\text { UNISOL. }\end{array}$ & $\begin{array}{l}\text { Relação forte com } \\
\text { UNISOL. }\end{array}$ & $\begin{array}{l}\text { Teve forte apoio da } \\
\text { UNIFORJA/UNISOL } \\
\text { no início. Hoje está } \\
\text { mais distante. }\end{array}$ \\
\hline $\begin{array}{l}\text { Perfil d } \\
\text { trabalh }\end{array}$ & $\begin{array}{l}\text { Forte presença de } \\
\text { mulheres. } \\
\text { Média de idade mui- } \\
\text { to elevada. }\end{array}$ & $\begin{array}{l}\text { Baixa presença de } \\
\text { mulheres. } \\
\text { Média de idade mui- } \\
\text { to elevada. }\end{array}$ & $\begin{array}{l}\text { Baixa presença de } \\
\text { mulheres. } \\
\text { Média de idade mui- } \\
\text { to elevada. }\end{array}$ & $\begin{array}{l}\text { Baixa presença de } \\
\text { mulheres. } \\
\text { Média de idade muto } \\
\text { elevada. }\end{array}$ \\
\hline $\begin{array}{l}\text { Relação } \\
\text { contratados(as) } \times \\
\text { cooperados(as) }\end{array}$ & $\begin{array}{l}\text { Todos(as) coopera- } \\
\text { dos(as). }\end{array}$ & $\begin{array}{l}73 \% \text { dos(as) traba- } \\
\text { lharores(as) coopera- } \\
\text { dos(as). } \\
\text { Também conta com } \\
\text { trabalhadores(as) ter- } \\
\text { ceirizados(as). }\end{array}$ & $\begin{array}{l}54 \% \text { dos(as) } \\
\text { lhadores(as) } \\
\text { rados(as). }\end{array}$ & $\begin{array}{l}\text { Todos (as) coopera- } \\
\text { dos(as). }\end{array}$ \\
\hline Remuneração & $\begin{array}{l}\text { Acima da média do } \\
\text { mercado. } \\
\text { Diferença entre maior } \\
\text { e menor remuneração } \\
\text { não passa de } 5 \times \text {. }\end{array}$ & $\begin{array}{l}\text { Acima da média do } \\
\text { mercado. } \\
\text { Diferença entre maior } \\
\text { e menor remuneração } \\
\text { não passa de } 5 \times \text {. }\end{array}$ & $\begin{array}{l}\text { Acima da média do } \\
\text { mercado. } \\
\text { Diferença entre maior } \\
\text { e menor remuneração } \\
\text { não passa de } 5 \times \text {. }\end{array}$ & $\begin{array}{l}\text { Acima da média do } \\
\text { mercado. } \\
\text { Diferença entre maior } \\
\text { e menor remuneração } \\
\text { não passa de } 5 \times \text {. }\end{array}$ \\
\hline
\end{tabular}

Fonte: Elaborado pelo autor.

\section{PROBLEMATIZAÇÃO SOBRE O MOMENTO ATUAL DAS ERTS NO BRASIL: REFLEXÕES E CONTRIBUIÇÕES ÀS RESISTÊNCIAS DO TRABALHO}

O quadro das ERTs no Brasil atual confirma a tendência de declínio das experiências no país apontada desde os primeiros estudos do GPERT, em 2011. Tal fato contrasta com o aumento dessas experiências em países como Argentina e Uruguai, além de países europeus, como Itália e Espanha. Em 2017, as pesquisas registraram o encerramento de cerca de 30\% das experiências mapeadas anteriormente e a diminuição no número de trabalhadores(as) nas empresas que se mantinham ativas. Em 2020, verificou-se uma redução ainda maior do número de experiências e da quantidade de trabalhadores(as) envolvidos(as).

Considerando os trabalhos realizados pelo grupo nos últimos dez anos (citados anteriormente, publicados em 2013 e 2019), bem como os recentes levantamentos e entrevistas apresentados nas seções anteriores deste artigo, avalia-se que o declínio e/ou a falência das iniciativas não tem uma única causa. Nessa trajetória de pesquisas e acompanhamento de casos foi possível perceber que, embora todas as ERTs sejam afetadas pela crise econômica e política do país, os fatores preponderantes para os fechamentos não são idênticos. Há casos nos quais a 
concorrência com produtos chineses foi o principal elemento para o fechamento (como a Cooparj), outros que sofreram intervenções judiciais em contexto de dificuldades econômicas, conflitos internos, irresolução do processo de falência e da questão da propriedade da indústria (como o caso da Usina Catende), inclusive somando-se a interesses das classes dominantes e às disputas político-partidários regionais e nacionais (como também os casos da Cooperminas e da Flaskô) ${ }^{20}$.

Em comum, é possível afirmar que as experiências, ao longo das décadas, seguiram marginais e fragilizadas no acesso a recursos e políticas públicas no Brasil, como revelaram estudos anteriores (SÍGOLO, 2015; ARAÚJO et al., 2019). Certamente, esse fato contribuiu para o quadro de "refluxo das experiências". O desmonte pós-golpe de 2016 das (limitadas) políticas públicas federais para o setor, como as da Secretaria Nacional de Economia Solidária do Ministério do Trabalho e Emprego (SENAES-MTE) e de outros órgãos do governo federal, aprofundaram as dificuldades das ERTs, contribuindo fortemente para o encerramento de vários casos.

Como apontam pesquisas do grupo, apesar de muitos esforços dos(as) trabalhadores(as) e de parceiros(as) e militantes, incluindo alguns setores do governo, no período anterior ao golpe, nesses últimos anos diversas lutas pela recuperação de empresas no país não resistiram à tendência destrutiva do capitalismo contemporâneo, devido também à insuficiência e aos desacertos das políticas públicas. Ao analisar vários casos de encerramento das ERTs brasileiras, explicita-se em suas histórias que permanece inabalada a hegemonia das classes dominantes, a criminalização das lutas dos(as) trabalhadores(as), a repressão a seus avanços na conquista de espaços e recursos públicos e a omissão da sociedade e do poder público na defesa dos direitos das classes historicamente oprimidas.

Arelação com o Estado é uma questão central nas reflexões sobre o tema das recuperações de empresas por trabalhadores(as) no Brasil, repleta de contradições e questionamentos. As políticas públicas conquistadas nas últimas décadas, especialmente em âmbito federal, apesar de terem sido por vezes determinantes para o desenvolvimento e a manutenção de diversos casos de recuperação de empresas por trabalhadores(as) no país, foram insuficientes, limitadas e frequentemente inadequadas às realidades das ERTs, além de muitas vezes não terem conseguido promover a autonomia necessária para que as experiências pudessem sobreviver à descontinuidade das políticas.

Em um período de graves retrocessos nas políticas públicas e sociais no país, cabe também indagar em que medida a expectativa com relação à ação do poder público inibiu a organização mais autônoma dos trabalhadores(as), como ocorrida em momentos anteriores. Tais reflexões recolocam antigos e atuais debates sobre a relação das lutas autogestionárias com o Estado. Em especial, nesse contexto de profunda crise pandêmica global são acirradas as disputas pelo acesso ao poder e aos recursos públicos, explicitando ainda mais os conflitos entre projetos políticos e de desenvolvimento, que se contrapõem na escolha por focalizar recursos públicos a grandes empresas capitalistas ou a organizações de trabalhadores(as) e pequenos produtores.

Apesar de tantos retrocessos nesta segunda década do século XXI, também é importante apontar que seguem emergindo experiências de recuperação de empresas por trabalhadores(as) no mundo, como destacam estudos sobre os casos na Argentina. Tal fato sinaliza a hipótese de que seguirão emergindo casos enquanto houver dominação e exploração do trabalho, como prova da capacidade de autogestão dos(as) trabalhadores(as), e também prefigurações para a construção de uma sociedade livre e democrática.

\footnotetext{
${ }^{20}$ Os casos da Cooparj, Usina Catende, Flaskô e Cooperminas foram analisados com mais detalhes em Araújo et al. (2019).
} 
Nesse sentido, seguem atuais e necessários os estudos sobre essas experiências, em busca de seguir aprofundando o conhecimento sobre suas práticas. Como ilumina Walter Benjamin (1994), a história, tecida pela luta de classes, mantém-se aberta aos possíveis silenciados na experiência das classes trabalhadoras e populares ao longo da dominação capitalista. Resgatar histórias e experiências, que muitas vezes compõem o que esse pensador denomina de "história dos vencidos", permanece tarefa fundamental na luta pela transformação das relações desiguais e injustas de propriedade e produção que caracterizam o sistema capitalista.

Para além do término de dezenas de experiências, que tem a ver com a grave crise econômica pela qual passa o Brasil, a outra questão que preocupa no atual cenário é o baixo número de novos casos de recuperação de empresas no país. Embora tenham sido registrados seis casos recentes de ocupações de empresas, alguns significativos, como das empresas Mabe e Kharmann Ghia, foi consolidado apenas um novo caso de recuperação, o qual não foi fruto de um processo de ocupação. Apesar de algumas dessas experiências de ocupação terem criado interlocução com assessorias e manifestado interesse em concretizar a recuperação da empresa pelos(as) trabalhadores(as), elas não tiveram êxito. Nesse ponto, é interessante analisar que a estratégia de recuperação de empresas em autogestão está muito distante e ausente das pautas e perspectivas de luta em debate no movimento sindical em geral e nas organizações de apoio aos(às) trabalhadores(as) no Brasile ${ }^{21}$.

Durante esse mesmo período, a Argentina passou por uma forte crise econômica e o movimento de empresas recuperadas sofreu ataques por parte do governo de Mauricio Macri (como o aumento do corte de energia e o veto à expropriação do Bauen, aprovado no Congresso). Além do aumento no número de experiências, conforme estudos do Programa Facultad Abierta ${ }^{22}$, é notório o fortalecimento do movimento das ERTs na Argentina, assim como a legitimidade política e social dessa estratégia de luta, como observado por Henriques (2014). Em recente encontro realizado por empresas recuperadas argentinas, frente à ameaça de despejo de uma empresa recuperada, a Cerâmica Neuquén, foi emitida uma Declaração ${ }^{23}$, da qual estão reproduzidos alguns trechos a seguir:

Por eso nos unimos trabajadores y trabajadoras de todas las fábricas recuperadas, que son una conquista de todo el pueblo argentino, para exigir una salida para nuestras gestiones obreras. Tenemos por detrás una historia de lucha. [...] Queremos que las gestiones obreras sean un ejemplo a seguir. Que las empresas donde haya cierre o despidos masivos sean ocupadas y puestas a producir por sus trabajadores. Que pongamos nuestro trabajo al servicio de la comunidad, [...] Buscamos la unidad de trabajadores, de las fábricas bajo gestión obrera y la unidad con toda la clase trabajadora para pelear unidos para que esta crisis no la paguemos nosotros sino los grandes empresarios. Llamamos a todas "las recuperadas" a ponernos en pie, todas juntas. Convocamos a todos los sindicatos, a los artistas que siempre nos apoyan, a los estudiantes, a los diputados y diputadas solidarios con las luchas del pueblo a que sean parte de esta pelea y esta campaña en defensa de "las fábricas sin patrón". [...] TOCAN A UNA TOCAN A TODAS.

\footnotetext{
${ }^{21}$ Um exemplo: em agosto de 2020, em meio a diversas fábricas e empresas em crise, o grupo de pesquisa foi contatado por uma assessora sindical, em busca de informações para apresentar o tema das ERTs a sindicalistas de Passo Fundo-RS, os quais desconheciam essas experiências, mesmo sendo a Região Sul do país importante palco de diversas lutas por recuperação de empresas por trabalhadores na história.

22 Programa da Universidade de Buenos Aires (UBA): www.recuperadasdoc.com.ar. Acesso em: 22 dez. 2020.

${ }^{23}$ Organizado virtualmente em 18 de julho de 2020, o "Encuentro de fábricas y empresas recuperadas y cooperativas de trabajo en defensa de las gestiones obreras", convocado pela Cerámica Neuquén e pela gráfica Madygraf, teve a participação de 16 fábricas recuperadas de distintas regiões da Argentina (Dados disponíveis em: https:// observatoriodeconflictividad.org/informe-sobre-el-encuentro-de-fabricas-y-empresas-recuperadas/).
} 
En el Encuentro resolvemos: 1) Conformar una Mesa de empresas bajo gestión obrera independiente de todos los gobiernos para coordinar nuestra defensa común, llamando a que se integren todas las cooperativas para luchar [...] ningún gobierno va a solucionar nuestros problemas y le exigimos a las centrales y sindicatos que apoyen nuestra lucha. 2) Al mismo tiempo llamamos a una Jornada nacional de lucha donde cada fábrica planifique acciones para hacer visible nuestra situación y pelear por nuestros reclamos. [...] 3) Impulsar una gran campaña nacional e internacional de pronunciamientos de en apoyo a las gestiones obreras. 4) Organizar nuevo encuentro para seguir unidos y coordinando la lucha (OBSERVATORIO DE CONFLICTIVIDAD, 2020).

Esse cenário contrasta fortemente com o que vivencia o Brasil. Para além das falências e da quase inexistência de novos casos de recuperação, identifica-se uma completa dispersão entre as experiências brasileiras, o que é confirmado na dificuldade em obter informações sobre o conjunto das empresas. Os representantes de uma empresa dificilmente têm informações sobre outras ERTs, e as entidades de assessoria dispõem apenas de informações sobre as empresas filiadas e encontram dificuldade de se comunicar e articular com outras experiências. O encontro argentino descrito anteriormente reuniu diferentes movimentos de empresas recuperadas, com concepções políticas distintas, para discutir uma agenda comum, considerando o risco de despejo de uma empresa.

Ao contrastar esse fato com o quadro encontrado nas pesquisas nacionais, é possível apontar a ausência de um movimento de empresas recuperadas por trabalhadores(as) no Brasil capaz de fazer frente à forte tendência de declínio apontada desde as primeiras pesquisas do GPERT. As pressões do mercado, o envelhecimento da geração de trabalhadores(as) que empreenderam essas lutas, a dificuldade de renovação desses quadros com jovens de formação técnica e política engajados na perspectiva da autogestão, o enfraquecimento das entidades de assessoria e de apoio técnico e político das experiências, o isolamento e a fraca articulação entre elas, somados à completa ausência de políticas públicas voltadas ao setor, colocam desafios enormes às resistências e lutas dos(as) trabalhadores(as) das ERTs brasileiras hoje.

Ao analisar o contexto argentino, verifica-se que mesmo com a oposição do governo Macri as empresas recuperadas argentinas nunca saíram completamente da pauta governamental e, no momento atual, em um cenário mais favorável, passaram a contar com instituições do governo para elaborar políticas para o setor, como o Programa Recuperar ${ }^{24}$.

No Uruguai, como identificado por Rieiro (2019), a política de crédito impulsionada durante o governo Mujica, com o Fondo para el Desarrollo (Fondes-Inacoop) ${ }^{25}$, entre outros fatores, fez as experiências de recuperações por trabalhadores(as) subirem de 20 para 50 casos entre 2008 e 2015. Após esse período, apesar de uma redução importante no número de experiências no país ${ }^{26}$, que em 2019 totalizavam 29 ERTs, o Uruguai segue registrando novos casos de recuperações, segundo Rebón e Rieiro (2020).

Ao acompanhar as lutas dos(as) trabalhadores(as) das ERTs brasileiras nesses últimos anos, o GPERT identificou uma série de limites e contradições que ajudam a entender a situação vivida por essas empresas na atualidade. $\mathrm{O}$ momento de extrema fragilidade dessas experiências

\footnotetext{
${ }^{24}$ Programa Recuperar: https://www.argentina.gob.ar/noticias/mas-de-400-empresas-recuperadas-se-fortalecengracias-al-programa-recuperar. Acesso em: 22 dez. 2020.

${ }^{25}$ Fondes-Inacoop: https://uruguayemprendedor.uy/programa-de-apoyo/fondo-para-el-desarrollo-fondes-inacoopinacoop/. Acesso em: 22 dez. 2020.

${ }^{26} \mathrm{O}$ crescimento vertiginoso de casos após a criação do FONDES indica que o acesso a recursos motivou muitas iniciativas de recuperação, que não se efetivaram, por não conseguir manter a produção (REBÓN; RIEIRO, 2020).
} 
nos convoca a lembrar das conquistas e dos aprendizados acumulados nesse longo percurso de lutas. Conforme destacado no relato da Metalcoop, a gestão pelos(as) trabalhadores(as) promoveu, em muitas empresas, melhores condições de saúde e segurança na fábrica. A redução significativa na desigualdade da distribuição dos rendimentos da produção é outra conquista importante que se destaca em um conjunto muito amplo de experiências. Por fim, a manutenção de milhares de postos de trabalho, por mais de 20 anos, que de outra forma teriam sido eliminados pela pressão da lógica e do mercado capitalista, certamente é a maior e a principal conquista. De acordo com um trabalhador de uma empresa metalúrgica recuperada argentina:

Una cooperativa exitosa es la que puede crecer generando muchas fuentes de trabajo. Pero las otras también tienen mérito, las que han logrado permanecer durante todo este tiempo. Para mí, una cooperativa exitosa es la que ha logrado perdurar (REBÓN, 2020).

A próxima seção deste artigo esboça uma agenda de pesquisa, considerada fundamental para avançar na compreensão do tema. Como grupo de pesquisa, o desafio proposto é seguir divulgando a história das ERTs no Brasil, assim como apoiar as experiências e contribuir para fazer transbordar aprendizados acumulados entre elas e também com novas formas de luta dos(as) trabalhadores(as).

\section{CONSIDERAÇÕES FINAIS - AGENDA FUTURA DE PESQUISA}

No quadro de grave crise global, agravada fortemente pela pandemia, o balanço sobre as estratégias de resistência das classes trabalhadoras e populares torna-se fundamental. Em contexto de disputa sobre caminhos e projetos para o enfrentamento da crise, acirram-se as desigualdades socioeconômicas e os conflitos de classes, com o aprofundamento da precarização dos direitos de trabalho e do desemprego.

Em busca da transformação do modo de produção e reprodução social do capitalismo, que orienta o modelo de desenvolvimento econômico e de industrialização que conduziu a humanidade às catástrofes sociais, ambientais e econômicas da atualidade, as experiências de recuperação de empresas por trabalhadores(as) em autogestão são referências importantes. Em diálogo com experiências de outros países, especialmente latino-americanos, as reflexões e os estudos sobre o fenômeno geram subsídios à construção de estratégias frente à profunda crise do mundo do trabalho atual.

Nesse sentido, o grupo vem construindo uma agenda futura de pesquisas, com vistas a contribuir com o aprofundamento das reflexões sobre o tema. Com o intuito de ampliar os debates, são questões orientadoras para o próximo período de trabalho:

- O que aconteceu com a experiência acumulada nos casos encerrados? Como os aprendizados da luta pela autogestão foram aproveitados (ou não) em seus territórios e comunidades? Onde estão e o que fazem hoje os trabalhadores(as) das experiências encerradas e suas famílias? Identificam-se aprendizados dessa experiência na fábrica e no trabalho em outras esferas de suas vidas?

- O que e como outros movimentos sociais e populares podem aprender com as experiências das ERTs? Como tais movimentos podem fortalecer (ou não) novos momentos de luta pela recuperação de empresas? Como as ERTs estão (ou não) conectadas com outros movimentos sociais e populares e quais são suas pautas de luta na atualidade? 
- Como a luta pela autogestão nas empresas recuperadas pode se fazer interseccional, abordando questões de gênero e de raça e problematizando a reprodução social, enquanto busca recriar as lógicas de produção de mercadorias? Como essa luta pode incorporar e se relacionar com a questão da reconstrução e das políticas dos comuns?

Essas questões buscam lançar adiante nosso olhar, com vistas a ampliar as reflexões e a articulação entre formas de luta e produção de conhecimento. Apresentar perspectivas futuras de pesquisa, em contexto de graves ataques às conquistas democráticas, às universidades e à educação públicas, à produção de conhecimento e à ciência, constitui também uma forma de resistência.

\section{REFERÊNCIAS}

ARAÚJO, Fernanda. Gestão do trabalho na COOPERMINAS: mobilização de competências e coletivos de trabalho na atividade dos operadores de uma mina de carvão em luta pela autogestão. Tese (Doutorado em Engenharia de Produção) - Escola de Engenharia, Universidade Federal Fluminense, Niterói, 2016.

ARAUJO, Fernanda; OLIVEIRA, Vicente; HENRIQUES, Flávio; SÍGOLO, Vanessa Moreira; POMPEU, Lucca; ATOLINI, Tarcila. (Orgs.). Dialética da autogestão em Empresas Recuperadas por Trabalhadores no Brasil. Marília: Lutas Anticapital, 2019.

AZEVEDO, Alessandra Bandeira; SOUZA, Sueline; GONÇALVES FILHO, Anastácio Pinto. Autogestão e a cultura da segurança do trabalho na Metalcoop e na Copromem. In: ARAUJO, Fernanda et al.(Org.). Dialética da autogestão em empresas recuperadas pelos trabalhadores no Brasil. Marília: Lutas Anticapital, 2019.

BENJAMIN, Walter. Obras Escolhidas I - Magia e técnica, arte e política. São Paulo: Ática, 1994.

ESTEVES, Egeu Gomez. Autogestão e Identidade: a experiência dos trabalhadores da Metalcoop. 2010. Tese (Doutorado em Psicologia) - Instituto de Psicologia, Universidade de São Paulo, São Paulo, 2010.

FARIA, Maurício Sardá de. Autogestão, cooperativa, Economia Solidária: avatares do trabalho e do capital. Florianópolis: Editora da UFSC, 2011.

HENRIQUES, Flávio Chedid. Autogestão em empresas recuperadas por trabalhadores: Brasil e Argentina. Florianópolis: Insular, 2014.

HENRIQUES, Flávio Chedid; FRANKEL, R. D. A experiência de assessoria a uma fábrica gerida por seus trabalhadores: o caso Cooparj. In: ADDOR, F.; LIANZA, S. (Org). Percursos da Extensão Universitária. Rio de Janeiro: Editora UFRJ, 2015.

HENRIQUES, F. C.; SIGOLO, V.; RUFINO, S.; ARAUJO, F.; NEPOMUCENO, V.; GIROTTO, M.; PAULUCCI, M.A.; RODRIGUES, T.N.; ROCHA, M.C.; FARIAS, M. Empresas Recuperadas por Trabalhadores no Brasil. Rio de Janeiro: Multifoco, 2013.

GUILLERM, Alan; BOURDET, Yvon. Autogestão: uma mudança radical. Rio de Janeiro: Zahar, 1976.

LEFEBVRE, Henri. Lógica formal, lógica dialética. Rio de Janeiro: Civilização Brasileira, 1995. 
MARX, Karl. Manuscritos Econômicos-Filosóficos. São Paulo: Boitempo, 2004.

MOTHÉ, Daniel. L'autogestion gouthe a gouthe. Paris: Editions du Centurion, 1980.

NASCIMENTO, Claudio. Do "Beco dos Sapos" aos canaviais de Catende: Os "ciclos longos" das lutas autogestionárias. Brasília: Senaes-MTE, 2005.

OBSERVATORIO DE CONFLICTIVIDAD. Informe sobre el Encuentro de Fábricas y Empresas Recuperadas, 18 de julio de 2020. Disponível em: https://observatoriodeconflictividad.org/ informe-sobre-el-encuentro-de-fabricas-y-empresas-recuperadas/. Acesso em: 18 de nov. 2020.

SANTOS, Boaventura Souza. et al. As epistemologias do Sul num mundo fora do mapa. Sociologias [on-line], v. 18, n. 43, p. 14-23, 2016.

SÍGOLO, Vanessa Moreira. Trabalho em moviment'ação': a formação de movimentos sociais de Economia Solidária no Brasil e na Argentina pós-90. 2007. Dissertação. (Mestrado em Integração da América Latina) - Programa de Pós-Graduação Integração da América Latina Universidade de São Paulo, Universidade de São Paulo, São Paulo, 2007.

. A contrapelo: autogestão, recuperação de empresas e a Usina Catende em Pernambuco. 2015. Tese. (Doutorado em Sociologia) - Faculdade de Filosofia, Letras e Ciências Humanas, Universidade de São Paulo, São Paulo, 2015.

SINGER, Paul. Uma utopia militante: repensando o socialismo. Petrópolis: Vozes, 1998.

THIOLLENT, Michael Jean Marie; COLETTE, Maria Madalena. Pesquisa-Ação, Universidade e Sociedade. Revista Mbote, Salvador, v. 1, n. 1, p. 42-66, jan./jun. 2020.

THOMPSON, Edward Palmer. A formação da classe operária inglesa III: a força dos trabalhadores. Rio de Janeiro: Paz e Terra, 1987.

UNIFORJA. Missão, visão e valores. Disponível em: https://uniforja.com.br/missao-visao-evalores/. Acesso em: 18 nov. 2020.

REBÓN, Julián. Factores positivos para el éxito cooperativo de las empresas recuperadas. Universidad de Buenos Aires. Instituto de Investigaciones Gino Germani - UBA, 2020.

REBÓN, Julián; RIEIRO Anabel Castiñeira. Consolidación cooperativa de empresas recuperadas por sus trabajadores en Argentina y Uruguay. Psicoperspectivas, Montevideo, v. 19, n. 2, 2020.

RIBEIRO, Luis. A cultura organizacional em empresas recuperadas por cooperativas de trabalhadores no Rio Grande do Sul. 2018. Tese (Doutorado em Ciências Sociais) Universidade do Vale do Rio dos Sinos, São Leopoldo, 2018.

RIEIRO, Anabel Castiñeira. Recuperación colectiva del trabajo y nuevas tramas de sociabilidad. El caso de las empresas recuperadas por sus trabajadores en el Cono Sur. Miríada, Montevideo, año 11, n. 15, p. 155-183, 2019.

Recebido em: 29/08/2020

Aceito para publicação em: 30/11/2020 